\title{
Progress in Flexible Electronic Textile for Heating Application: A Critical Review
}

\author{
Md. Reazuddin Repon *[i] and Daiva Mikučionienė (1)
}

Citation: Repon, M.R.; Mikučionienè, D. Progress in Flexible Electronic Textile for Heating Application: A Critical Review. Materials 2021, 14, 6540. https://doi.org/10.3390/ ma14216540

Academic Editors: Gabriele Milani, Georgios C. Psarras and Seung Hwan Ko

Received: 30 September 2021

Accepted: 26 October 2021

Published: 30 October 2021

Publisher's Note: MDPI stays neutral with regard to jurisdictional claims in published maps and institutional affiliations.

Copyright: (c) 2021 by the authors. Licensee MDPI, Basel, Switzerland. This article is an open access article distributed under the terms and conditions of the Creative Commons Attribution (CC BY) license (https:/ / creativecommons.org/licenses/by/ $4.0 /)$.

\author{
Department of Production Engineering, Faculty of Mechanical Engineering and Design, Kaunas University of \\ Technology, Studentu 56, LT-51424 Kaunas, Lithuania; daiva.mikucioniene@ktu.lt \\ * Correspondence: reazmbstu.te@gmail.com; Tel.: +370-66227098
}

\begin{abstract}
Intelligent textiles are predicted to see a 'surprising' development in the future. The consequence of this revived interest has been the growth of industrial goods and the improvement of innovative methods for the incorporation of electrical features into textiles materials. Conductive textiles comprise conductive fibres, yarns, fabrics, and finished goods produced using them. Present perspectives to manufacture electrically conductive threads containing conductive substrates, metal wires, metallic yarns, and intrinsically conductive polymers. This analysis concentrates on the latest developments of electro-conductivity in the area of smart textiles and heeds especially to materials and their assembling processes. The aim of this work is to illustrate a potential trade-off between versatility, ergonomics, low energy utilization, integration, and heating properties.
\end{abstract}

Keywords: conductivity; heating element; knitting; metal fibre; smart textiles

\section{Introduction}

With the progression of electronic device miniaturization and the Internet of Things (IoT), the scope of flexible wearable electronics has been increasing in our quotidian appliances. For the successful construction of flexible electronics, textiles fibrous materials have received tremendous attention because of their excellent deformability, soft feel, comfort, lightness, good absorption, and moistures properties. In general, textiles are used for clothing purposes and with the rapid growth of advanced manufacturing strategies, fibrous textiles are now acquainted as an ideal material for electronic device engineering and fabrication. The electronic textile (e-textile) can provide information that can effectively respond to and adjust actions, capable of sensing external conditions or stimuli. The stimuli can be thermal, mechanical, chemical, electrical, magnetic, optical, etc. [1-6]. According to the applications, smart textiles can be classified into three sorts: the first generation of smart textiles incorporating sensors, which can track or stimulate environmental changes is referred to as passive e-textiles; the second generation includes textiles containing sensors and actuators that give the capability to recognize and actuate or passage a part of their environment (chromatic materials, shape memory materials, phase change materials, hydrogels and membranes), which are defined as active e-textiles; lastly, the third generation of smart textiles, which can feel, respond, and accept peripheral circumstances or stimuli (space suits, thermoregulating clothing, health monitoring apparel), includes sophisticated or very e-textiles [7-11].

The materials, related to textiles, show conductivity or work on an electronic or computational purpose, referred to as conductive textiles, and these are used for an ample variety of textile fibre-based goods with certain electrical conductivities that vary widely [12]. Conductive fibres, yarns, fabrics, and also garments are included in conductive textiles [1]. They are required even for smart textiles to work. Their value determines smart textiles' durability, launderability, reusability, and fibrous efficiency [13]. For antistatic applications, electromagnetic interference shielding (EMI), electronic applications, infrared absorption or protective clothing in dangerous areas, filters, de-electrifying coatings and anti-electrostatic 
and heating purposes, conductive fabrics have received increased interest. This is often largely because they are desirably versatile and lightweight [14-20]. Important advantages are gained by the textile industry within the fields of intelligent and multifunctional textile products, particularly in advanced fibres, yarns, and fabrics. Additionally, industrial materials such as sensors, electrostatic discharge, electromagnetic interference shielding, dust- and germ-free clothing, monitoring, data transfer in clothing, etc. are increasingly rising in demand for fabrics (eventually, fibres and yarns with improved electrical conductivity) [21,22]. It is possible to classify conductive fibres into two groups: those that are normally conductive, and others that are specifically treated for conductive formation. Electrically conductive metals-for example, ferrous alloys, nickel, stainless steel, titanium, aluminium, copper, and carbon-are formed from naturally conductive fibres or metallic fibres. Using coating fibres by metals, conductive polymers, galvanic substances, or metal salts such as copper sulphide and copper iodide, electrically conductive fibres can also be made. Another method comprises the preparation of polymer fibre, whose chemical configuration itself guarantees superior conductivity or the application of conductive bi-component fibres.

Conductive fibres may be manufactured in filament or staple lengths to produce yarns with varying degrees of conductivity and might be integrated with conventional fibres. Without greatly altering the existing substrate properties, conductive coatings can convert substrates into electrically conductive materials. It may be implemented to the outward of fibre, yarn, or fabric via methods comprising electroless plating, evaporative deposition, sputtering, and conductive polymer coating. There is an alternative opportunity to develop conductive textiles by printing with ink that is conductive. Conductive inks are used to print patterns on fabric and those prints show electrical activity. To produce conductive inks, metals such as copper, silver, gold, carbon, and nickel are injected to conventional printing inks. Different external factors such as strain, torsion, $\mathrm{pH}$, and humidity may be responsible for altering the conductivity of textile materials. For multiple novel applications, the resulting conductive textile is acceptable. Classically used electroactive materials and their properties for e-textiles are indicated in Table 1 . Some chemical structures of polymeric, metallic, and carbon-based electroactive materials for e-textiles are presented in Figure 1 and electrical conductivity vs. Young's modulus of different electroactive fibres as well.

Table 1. Typically used electroactive materials and their properties for e-textiles.

\begin{tabular}{|c|c|c|c|c|}
\hline Electroactive Materials & $\begin{array}{l}\text { Group of Electroactive } \\
\text { Materials }\end{array}$ & $\begin{array}{l}\text { Limit of Electrical } \\
\text { Properties }\end{array}$ & Strengths and Weaknesses & Refs. \\
\hline $\begin{array}{l}\text { Metallic flakes/nanoparticles/ } \\
\text { nanowires (e.g., } \\
\mathrm{Cu} / \mathrm{Ag} / \mathrm{AgNWs} / \mathrm{Au} / \mathrm{Ni} / \mathrm{Al} \text { ) }\end{array}$ & $\begin{array}{l}\text { Metal and its } \\
\text { derivatives }\end{array}$ & $\approx 10^{4}-6.3 \times 10^{7} \mathrm{Sm}^{-1}$ & $\begin{array}{ll}\text { - } & \text { Extremely conductive } \\
\text { - } & \text { Resistant against air ageing } \\
\text { - } & \text { Inflexible } \\
\text { - } & \text { Less comfort }\end{array}$ & [23] \\
\hline PANI/PPy/PEDOT: PSS/PhT & $\begin{array}{l}\text { Intrinsically conducting } \\
\text { polymers (ICPs) }\end{array}$ & $\approx 10-1.7 \times 10^{-3} \mathrm{Sm}^{-1}$ & $\begin{array}{l}\text { - } \quad \text { Less cost and density } \\
\text { - } \quad \text { Non-resistant to air ageing }\end{array}$ & {$[24]$} \\
\hline $\begin{array}{l}\mathrm{CB} / \mathrm{CNF} / \mathrm{GO} / \mathrm{rGO} / \mathrm{MX} \text { ene/ } \\
\mathrm{SWCNT} / \mathrm{MWCNT}\end{array}$ & $\begin{array}{l}\text { Carbonaceous } \\
\text { materials }\end{array}$ & $\approx 10^{2}-10^{9} \mathrm{Sm}^{-1}$ & $\begin{array}{l}\text { - Highly conductive } \\
\text { and stretchable } \\
\text { - } \quad \text { Time-consuming process }\end{array}$ & {$[25,26]$} \\
\hline
\end{tabular}

Note: $\mathrm{Cu}=$ copper; $\mathrm{Ag}=$ silver; $\mathrm{AgNWs}=$ silver nanowires; $\mathrm{Au}=$ gold; $\mathrm{Ni}$ = nickel; $\mathrm{Al}$ = aluminium; $\mathrm{PANI}$ = polyaniline; $\mathrm{PPy}=$ polypyrrole; PEDOT: PSS = poly(3,4-ethylenedioxythiophene) polystyrene sulfonate; PhT = triethoxy (phenyl); $\mathrm{CB}=$ carbon black; CNF = carbon nanofibres; $\mathrm{GO}$ = graphene oxide; $\mathrm{rGO}=$ reduced graphene oxide; $\mathrm{SWCNT}=$ single-walled carbon nanotube; $\mathrm{MWCNT}=$ multi-walled carbon nanotube. 


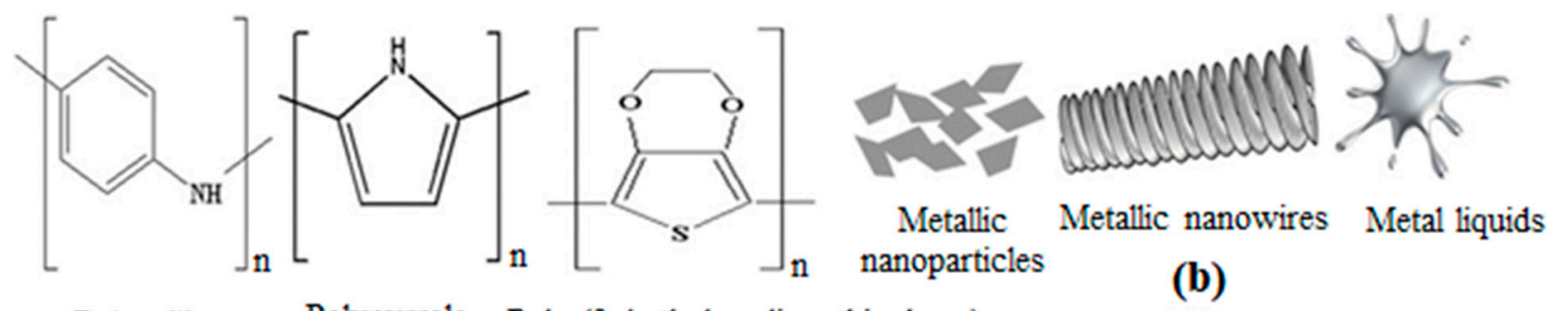

Polyaniline

Polypyrrole
(PPy)

Poly (3,4 ethylenedioxythiophene)

(b)

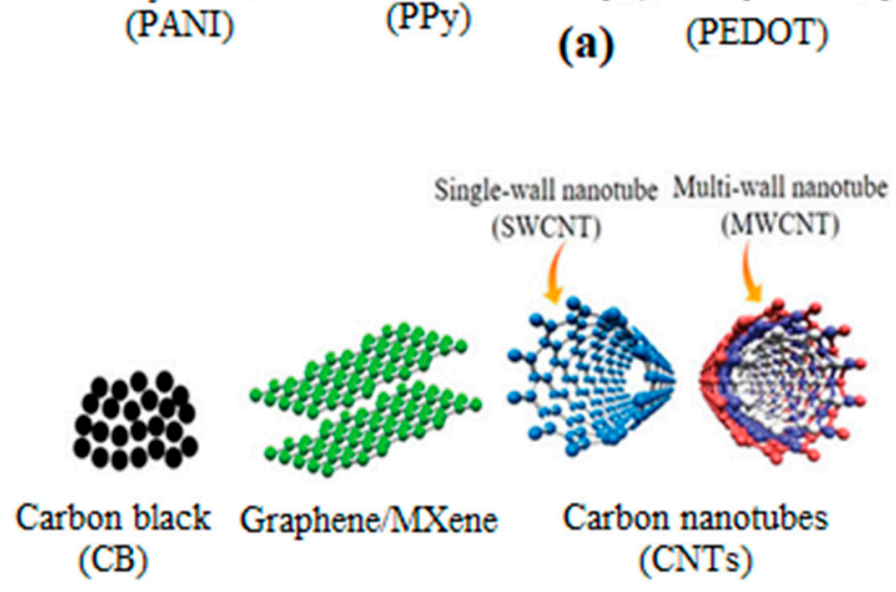

(c)

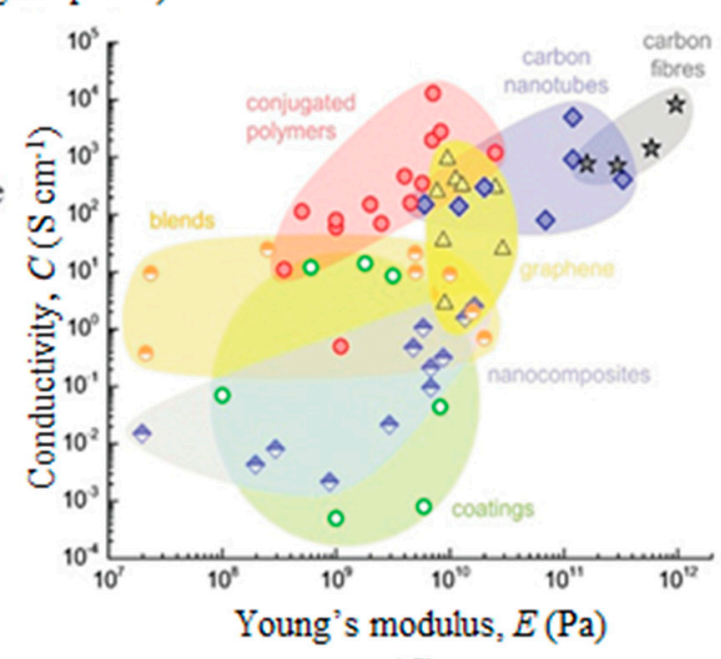

(d)

Figure 1. (a) Polymeric, (b) metallic, and (c) carbon-based electroactive materials for e-textiles. (d) Electrical conductivity vs. Young's modulus of different electroactive fibres based on CNTs (blue diamonds), carbon fibers (gray stars), ICPs (red circles), blends of conjugated and insulating polymers (orange/white circles), graphene (yellow triangles), nanocomposites of CB (blue/white diamonds), CNTs or graphene embedded in an insulating polymer matrix and (green/white circles) coatings of textile fibers with ICPs, CNTs, or graphene [27].

\section{Conductive Textile Architectures}

\subsection{Conductive Fibre/Yarns}

Some specific fibres that are conductive electrically are remarkable in textile history. A fibre can be described as a fine, flexible structure that has a high length-to-width ratio [28]. A fibre having an electro-conductive part can be described as conductive fibre. Thick copper wires or metal nails are electro-conductive, but they cannot be defined as fibre, since they are neither fine nor flexible. However, polymer fibre with a silver coating or fine copper wire can be identified as conductive fibres [20]. Wire drawing, a mechanical method of processing, is the traditional process of creating metal fibres. The numerous drawing measures, called coarse, medium, fine, and carding train, characterize this method (Figure 2) [10]. The drawing dies are composed of a steel mount with a centre made from ceramics, carbide, or diamond that is used for drawing the fibre. Depending on the material, the opening diameter of the metal wire fluctuates. It is typically $8 \mathrm{~mm}$ for copper, whereas it is $5 \mathrm{~mm}$ for iron. The wire is recycled at temperatures between 600 and $900{ }^{\circ} \mathrm{C}$ following drawing. They are eventually quenched. On a rotating wire drawing cylinder, the fine metal wire is then wrapped [29]. Metal monofilaments that can be intermingled with all kinds of fibres or can be employed without changing the direction in which weaving and knitting have been discovered. Significantly, there are different electrical characteristics in relation to the material used [30]. The products range from filaments made of copper $(\mathrm{Cu})$ and silver-plated copper $(\mathrm{Cu} / \mathrm{Ag})$, brass $(\mathrm{Ms})$ and silver-plated brass (Ms/Ag), and aluminium (Al) and copper-clad aluminium (CCA) filaments. Metal monofilaments that are inserted into base yarns such as cotton, polyester, polyamides, and aramids are specially manufactured by another company. A standard conductive yarn with base fibres and a 
metal monofilament twisted around them is shown in Figure 2. There, Shieldex Nylon 66 threads were used, which are coated as a base material with a thin silver layer [10]. The benefit of coatings is that they are appropriate for numerous categories of fibre and construct good conductivity without drastically modifying established main features, for example, density, flexibility, and handling. The adhesiveness of the metal and fibres plus the resistance of corrosion can, however, create problems.

Coatings may be functional to the outer part of fibres, yarns, even fabrics. Coatings on the conductive polymeric textile are carried out by sputtering, electroless plating, and deposition of vapour. In order to prepare conductive textiles, metal fibres are combined with traditional fibres during spinning [4,31,32]. During weaving and knitting, the processing of these yarns is difficult, consequential in fabrics with movable textile properties $[16,33]$. By coating CPs, such shortcomings connected with the processability and poor textile characteristics have been effectively solved [34]. PPy has been generally practiced by the CPs on account of its high conductivity, low toxicity, and high ecological constancy. It is presented in a system to produce fibres with diverse material layers and structures. The manufacturing process is based on the traditional fibre-processing based on the preform, easily generating kilometres of usable fibre during the process. Another important task is to produce a transistor using the crossing yarns [35,36].

Additionally, the carbon nanotube fibre is manufactured on the basis of tiny carbon nanotubes by means of the wet spinning method [37]. The groundwork and features of both conductive polymer-based fibres and nanocomposite fibres on a carbon nanotube basis are described in another paper [38]. Through melt spinning, carbon nanotubes containing conductive fine fibres were geared up with polyester, polyamide 66 , and polypropylene. Here, the results showed that by adding the amount of CNT, the electrical conductivity was amplified [39].

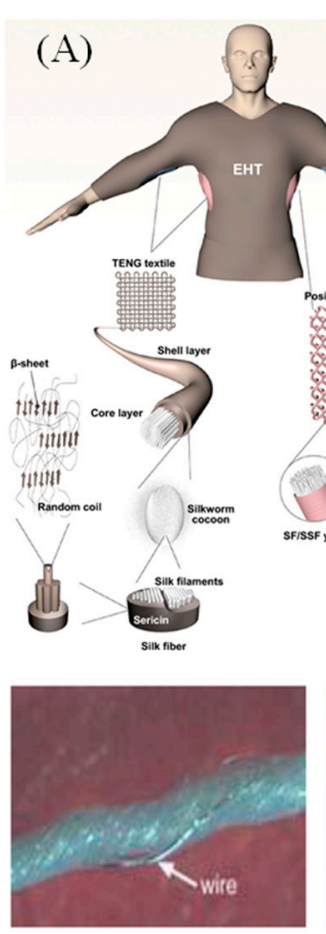

(a)

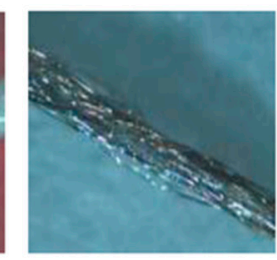

(b)

(B)

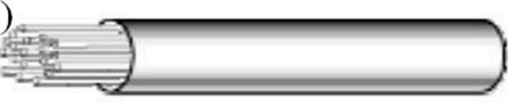

(a)

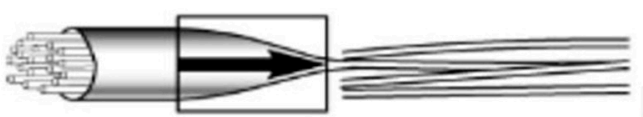

(b)

(c)

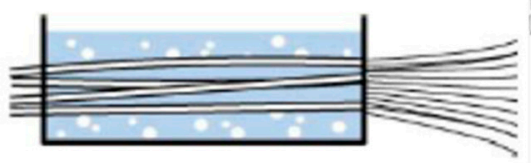

(d)

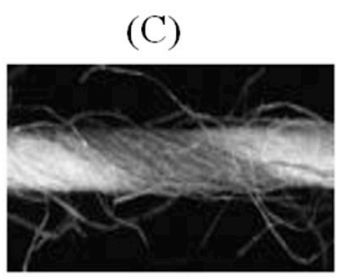

(c)

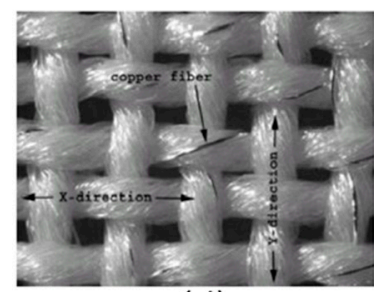

(d)

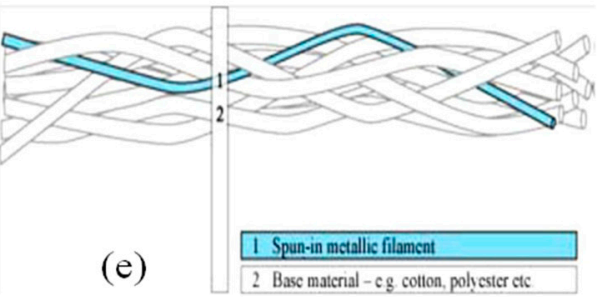

(e)

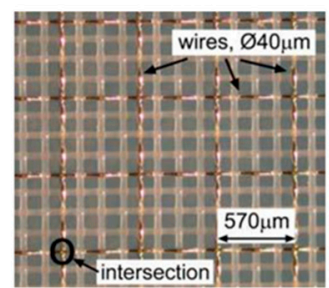

(e)

Figure 2. (A). Ultrastable and high-performance silk energy harvesting textiles; (B). (a) Iron tube; (b) reducing diameter; (c) tube building; (d) forming fibres and (e) conductive fibre diagram wrapped with the typical fibres; (C). (a) Twisted metal wire; (b) coated metal; (c) metal multi-filaments; (d) copper-polyester twisted yarn and (e) base fabric with embedded copper wire $[10,40,41]$. 


\subsection{Conductive Fabrics}

Conductive textile has been gained for multi-purpose and multi-directional applications by numerous means, for instance, chemical coating, metallisation, electroless deposition, metallic yarns insertion, and thin-layer plating that holds conductive fillers, for example, CNT and carbon black particles [42-45]. By utilizing weaving, knitting, and embroidery or nonwoven manufacturing methods, the function of electronics can be incorporated into the textile products. However, it is a complex and hardly ever uniform method to incorporate conductive yarns into an arrangement as it is necessary to make sure that the properties of the conductive fabric are suitable for wearing rather than stiff and inflexible. Various kinds of threads can be utilized to launch conductivity (Figure 2). Woven fabrics can include a multiplex network with various conducting and non-conducting components that can be used as complicated electrical circuits and are designed to provide several layers and spaces to accommodate electronic devices. A simple woven fabric containing polyester yarns twisted with copper thread has been developed by researchers at ETH. It is made of $42 \mu \mathrm{m}$ diameter woven polyester monofilament yarn and $50 \pm 8 \mu \mathrm{m}$ diameter copper alloy wires. A polyurethane varnish is used as insulation material to coat each copper wire. The copper wire grid has a separation of $570 \mu \mathrm{m}$ in the textile structure. Electrically conductive coatings for fibre-based e-textiles and silver nanowire coated knitted wool fabrics for wearable electronic applications are exhibited in Figure 3.

(A)

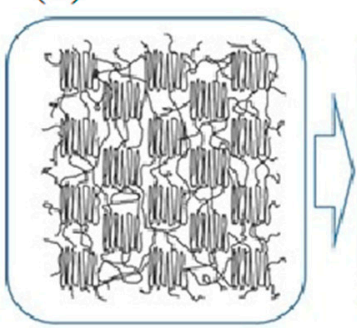

Molecules in a fibrillar structure $(\AA)$

(B)

Wool knitted fabric coated with AgNWs

Parafilm

Wool knitted fabric coated with AgNWs

(a)

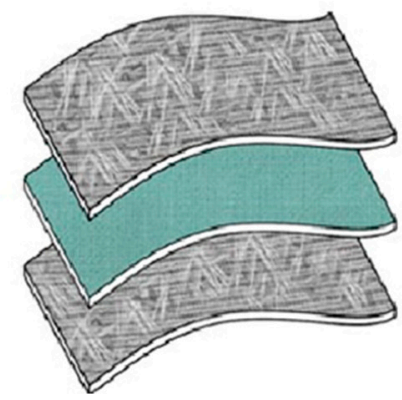

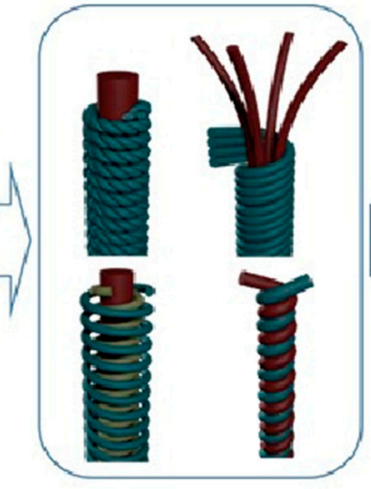

Yarns $(\mu \mathrm{m})$

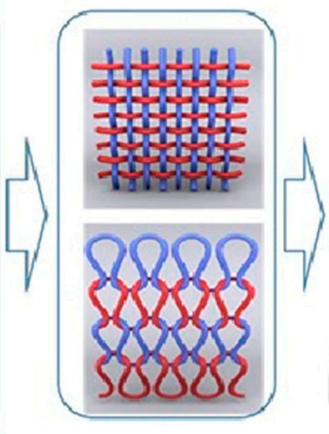

Fabrics (m)

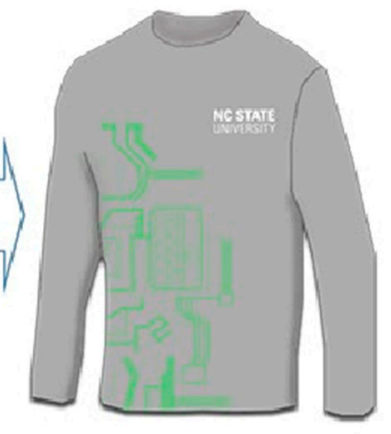

Textile product
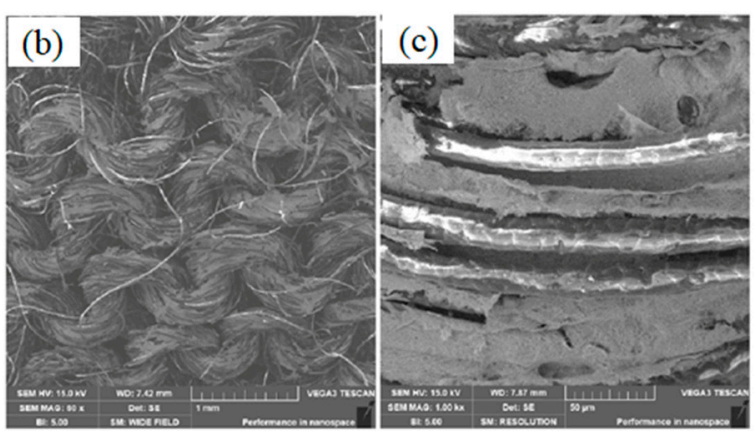

Figure 3. (A). Electrically conductive coatings for fibre-based e-textiles; (B). (a) Silver nanowire coated knitted wool fabrics for wearable electronic applications, SEM images of conductive knitting fabric after coating and washing with distilled water under (b) $60 \times$ and (c) $1000 \times$ magnifications $[28,46]$.

Feratec $^{\circledR}$ (Manufacturer: Baltex; Ilkeston, UK) can primarily be used for the specific heating and electro-magnetic shielding purposes. Here, knitting technology has been used to integrate metal wires. Metallized woven nylon fabrics have also been manufactured in various shapes and profiles. In order to produce metallized woven fabrics, silver, copper, and a copper-nickel combination are used as the metal. The conductive yarns-for example, copper thread, silver-plated, and polyester-coated-are used in manufacturing electronic fabrics, electronic conductors, textile operating panels, and micro-sensors. Conductive 
fabric can also be accomplished using the embroidery method by adding a conductive material to a ground arrangement. Stitching patterns that can identify circuit traces, connection pads, or sensing surfaces built with conventional CAD circuit layout tools have been discovered (Figure 2) [47]. High sensitivity to its elongation is shown by the surface resistance of PPy conductive fabric. By changing the resistance and anisotropic structure of the fabric, body joint motion can be identified [48-50].

\section{Thermoregulation for Conductive Textiles}

Textile materials are considered as ideal insulators and hold wide varieties of thermal conductivity at their pristine state. Conductive textile uses environmentally friendly electric energy that provides electrical energy by setting heating elements into the clothing [51]. The thermal conductivity of several materials is indicated in Table 2. In order to explain the heat generation phenomenon, Joule's law is used, wherein heat is generated by an electrical current passing through a heat-generating conductor inserted into the fabric. The power supply, flexible heating device, clothing, safety protection elements, and temperature control module are key elements of composing conductive heating textiles. Joule's heating principle describes the heat generation; the power of heating $(P)$ is related to the resistance $(R)$ and electric current $(I)$ of the conductor and is calculated by Equation (1).

$$
P=I^{2} R
$$

Table 2. The thermal conductivity of several materials [51].

\begin{tabular}{ll}
\hline $\begin{array}{l}\text { Indicators of Thermal Conductivity of } \\
\text { Thermal Insulators }\end{array}$ & Thermal Conductivity $\left(\mathbf{\lambda} / \mathbf{W m}^{-\mathbf{1}} \mathbf{K}^{-\mathbf{1})}\right.$ \\
\hline Wood & 0.17 \\
\hline Asbestos & 0.17 \\
\hline Plastics & 0.17 \\
\hline Leather & 0.15 \\
\hline Polystyrene & 0.1329 \\
\hline Polyacrylonitrile fibres & 0.05 \\
\hline Nylon & $0.209-0.337$ \\
\hline Polypropylene fibres & $0.22-0.30$ \\
\hline Cellulose & 0.11 \\
\hline Air & 0.0244 \\
\hline
\end{tabular}

When a resistor is connected to an external power source, it will produce heat. According to Joule's effect, the conductive textile material can be used as a resistor with a confirmed degree of conductivity for heat generation. To effectively affect Joule's heat generation theory, an electrical conductor necessitates a reasonable electrical resistivity. It is not possible to produce enough heat by a low-resistivity highly conductive material while passing a current through it. In order to produce resistive yarns or fabrics of conductive composite for heat generation, metal, a good conductive source, is then mixed with insulating textile fibres in a variety of ways $[52,53]$. The electrical conductivity, $\sigma$, is calculated by Equation (2) and the resistance, $R$, is calculated by Equation (3).

$$
\sigma=\frac{1}{\rho}
$$

and

$$
R=\rho \frac{l}{A}
$$


Thermal conductivity, $K$, is the material's property that indicates the ability to conduct heat and is calculated by Equation (4).

$$
H=\frac{\Delta \mathrm{Q}}{\Delta \mathrm{t}}=K A \frac{\Delta \mathrm{T}}{l}
$$

where $\Delta \mathrm{Q} / \Delta \mathrm{t}$ is the rate of heat transfer, $\rho$ is the electrical resistivity, $A$ is the surface area, and $l$ is the length.

The electrical and thermal energy sources are responsible for heat generation on textile materials. A suitable temperature gradient is maintained by textile heated clothing between the body and environment. It is possible to gain the necessary temperature gradient by either passive or active clothing. Where a high amount of work is needed, passive clothing is not sufficient. It impedes the wearer's ease as it contains some layers. In that case, active clothing can be an alternative. Graphite, metal, conductive rubbers, and water-like elements have been used before in active clothing to generate heat.

\section{Roadmap towards Heating Textile Devices}

In two ways, heated textiles can be produced: one is manufacturing a piece of fabric and adding an electronic mechanism into it, and another way is manufacturing a yarn with electronic characteristics and producing textile products [54]. In heating clothing and gloves, electrical wires were used. The gloves should be used with an outward cape-leather to keep away electric wires from skin contact [55]. In World War II, metallic wires were first used in textile clothing [56]. Rather than metallic wires, more advanced conductive yarns are fashioned, currently, containing the features of textile yarns [33]. Nonwoven, knitted, woven, and embroidery fabrics can be used to fabricate heating products. Due to high resistivity, heating elements containing nonwoven fabric have confirmed limited utilization. Alternatively, woven fabric marks lower resistance than knitted fabric in the same dimensional heating area because of the structure [57,58]. A multifilament carbon blended stainless steel yarn is generated with moderate resistance for an acceptable heat generation application [4]. This kind of electro-conductive yarn has been found to exhibit especially brittle and weak bending features which are not appropriate for textile applications $[59,60]$. A conductive textile was first recorded by De Rossi for measuring strain and temperature [61]. By coating polypyrrole on a Lycra fabric, the sensing fabric was fabricated and demanded to demonstrate temperature sensitivity, comparable to that of ceramic thermistors. However, in order to use it in a functional environment, they have not offered any additional description. Another significant drawback was that the fabric was so particularly susceptible to a strain that could also be a major cause of strain, well in a complex setting. This may be the main source of unwanted art-crafts during temperature management. To produce active clothing, external devices or heaters were used, though there were some limitations of using heaters: clothing weight up, structure rigidity, and sweat extraction. Heating small patches can be without problems joined in active clothing at several locations by stitching. Basically, a patch of heating is composed of four elements: a carrier, a heating material, a bus bar, and a power source. Many of the incidents recorded in recent years are attributed to aircraft caused by ice accumulation $[62,63]$. Heated textiles can also be exercised as an anti-freezing mediator in the aircraft industry to prevent ice accumulation on the aircraft wings.

Heating textile has therapeutic advantages, providing heat treatment against persistent pain [64]. As the surface of the heating textile remains in contact with skin, it shows effective results in thermotherapy. This textile is used in a particular region and the application of heat increases blood flow, reduces inflammation and pain, and is also used for joint injuries [65-67]. To inform patients of their pathological conditions, heating textiles can play a role as thermographs. It can monitor vascular, dermatological, and rheumatic abnormalities and investigate breast cancer [68]. In that case, thermocouples and thermistors are used as contact sensors and can be inserted into textiles without making 
them bulky [69]. In the next section, the recent progress in different electroactive materials coated heating textile is comprehensively discussed.

\section{Advanced Heating Textiles and Their Performances}

\subsection{Metal-Based Heating Textiles}

Metals are highly electro-conductive and have ideal electrical properties as well. That is why metal-integrated textiles are conductive and can be used for heating purposes. Frank Hewitt manufactured heating fabric and heating pads where heat was produced by electric current flow through a metal wire that was inserted into the fabric or pad [70-72]. Metal wires can be woven or knitted into the heating textile. The heating fabrics which have plain and interlocking knitted structures show maximum equilibrium temperature at the voltage of $3 \mathrm{~V}$ and stainless steel yarns are integrated as heating elements into the knitted fabrics where silver-plated yarn is braided on both sides of the fabrics [73]. A study shows that plain woven fabric which contains silver filament or silver-plated yarns has a great positive linear correlation between power and temperature. This relation improves the design of fabric manufacturing by analyzing the physical properties of heating textiles [57]. To prepare metal-based conductive heating textile, metal nanomaterials can be coated on the fabric surface. Compared to CNT-coated cotton fabric, AgNW-coated cotton fabric shows a better heating effect. The study shows that at the voltage of $0.9 \mathrm{~V}$ and $1.2 \mathrm{~V}$ AgNW-coated cotton fabric can reach $38{ }^{\circ} \mathrm{C}$ and $53^{\circ} \mathrm{C}$, respectively, whereas to obtain the same heating effect for CNT-coated cotton fabric, the voltage needs to be raised up to $12 \mathrm{~V}[74,75]$.

Liu et al. [76] knitted plain, rib, and interlock structures using silver-plated yarn and polyester staple yarn (Figure 4D). In the research, aging tests were carried out, and under $100{ }^{\circ} \mathrm{C}$ temperature, the silver-plated yarn was hardly affected by time and the aging temperature. A strong linear correlation was found between the power consumption density and the maximum equilibrium temperature of three knitted fabrics in the study. Another research work was carried out to test the electro-thermal stability of silver yarn or silver-coated yarn by performing an oven aging test; the results found better electrical resistivity of silver yarn by showing a strong linear density. At a voltage of $9 \mathrm{~V}$, that resistivity made the samples capable of obtaining higher temperatures [77,78]. Kexia et al. [78] showed the relation of temperature and the resistance of wool and silver yarn made conductive electro-thermal knitted fabric (Figure 4B). At a voltage of $2.4 \mathrm{~V}$, the conducting heating fabric showed a better result which had the double needle bed knitting structure of $1 \times 1 \mathrm{rib}$. Hong et al. [79] embedded AgNWs to polydimethylsiloxane (PDMS) films (Figure 4A). These conductive films showed extraordinary electrical conductivity that could respond to thermal properties quickly by generating Joule heating (Figure 4A). Guo et al. [80] used the roller printing method to create highly conductive wearable electronics for smart fabrics depending on the adhesion variance of semiliquid metal (Cu-EGaIn, eutectic gallium-indium combined with copper microparticles) on cotton fabrics and PVAC glue. The adhesive effect with the Cu-EGaIn mixture is determined by the surface topography and chemical interaction of textiles and PVAC glue, according to the findings. The electromechanical stability of the manufactured lines on fabrics was proved in the electric testing. To demonstrate practical applications in the method, a number of smart fabrics were constructed, including an interactive circuit, stretchy light-emitting diode array, and thermal management device with benefits of easy operation, low cost, and large-area fabrication (Figure 4C). Repon et al. [81] investigated heat generation in compression supports using Ag-coated PA-based electro-conductive knitted textiles. They created compression knitted constructions with integrated electro-conductive yarns and studied heat generation characteristics and temperature variations over time and under stretch to induce compression. Silver-coated PA yarn with linear densities of 66 tex and 235 tex was used to create combined half-Milano rib structured knitted fabrics. The summary of metal-coated heating textiles is shown in Table 3. 

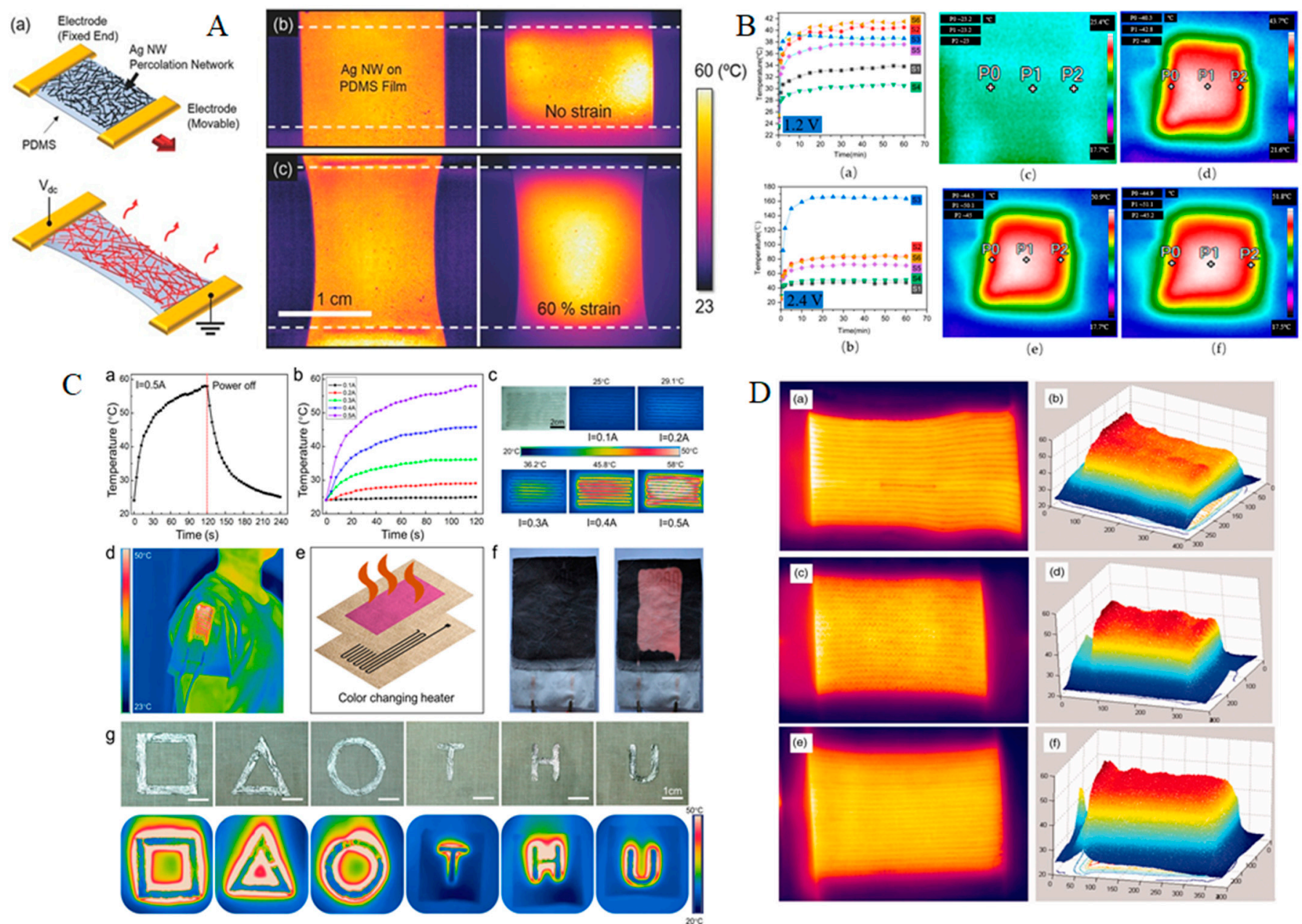

Figure 4. (A) Highly stretchable and transparent heater. (a) Schematic illustration of the stretchable and transparent heater composed of AgNW percolation network on PDMS film; (b,c) pseudocolor image at room temperature (left) and infrared camera thermal image (right) of a Ag NW/PDMS stretchable and transparent heater operating at $60{ }^{\circ} \mathrm{C}$ with (b) no strain and (c) at 60\% strain condition [79]; (B) sample temperature change with time of S1-S6 under (a) $1.2 \mathrm{~V}$ and (b) $2.4 \mathrm{~V}$ and thermal images of S4 (c) before and (d) after $1 \mathrm{~min}$, (e) after $30 \mathrm{~min}$, and (f) after $1 \mathrm{~h}$ of application of a voltage of 2.4 V [78]; (C) thermal management device printed on woven cotton fabrics. (a) Temperature curve of the serpentine Cu-EGaIn conductors during heating/cooling process under input current of $0.5 \mathrm{~A}$. (b) Temperature curve of the serpentine Cu-EGaIn conductors during the heating process under various input currents. (c) Picture of the thermal management device and its infrared temperature distribution images at $120 \mathrm{~s}$ under various input currents. (d) Infrared temperature distribution image of the thermal management device sewn on a T-shirt. (e) Structure diagram of the woven cotton fabric with color changing pigment. (f) Thermochromic display of the serpentine Cu-EGaIn conductors. (g) Infrared temperature distribution image of multiple Cu-EGaIn patterns heated by the electromagnetic heating coil [80]; (D) infrared images of (a) PSF, (c) RSF and (e) ILK and three-dimensional images of (b) PSF, (d) RSF and (f) ILK at 4 V [76]. 
Table 3. Summary of metal-coated heating textile.

\begin{tabular}{|c|c|c|c|c|c|}
\hline $\begin{array}{l}\text { Electroactive } \\
\text { Materials }\end{array}$ & Type of Textile & $\begin{array}{l}\text { Temperature } \\
\text { Range }\left({ }^{\circ} \mathrm{C}\right)\end{array}$ & $\begin{array}{l}\text { Voltage Range } \\
\text { (V) }\end{array}$ & $\begin{array}{l}\text { Electrical } \\
\text { Properties }\end{array}$ & Refs. \\
\hline AgNWs & $\begin{array}{l}\text { Cotton/Polyurethane } \\
\text { Core-Spun Yarn (CPY) }\end{array}$ & $\approx 25-100$ & $2-6$ & $\approx 36 \Omega \mathrm{sq}^{-1}$ & [82] \\
\hline AgNWs & Nylon & $\approx 30-140$ & $2-10$ & $30 \Omega \mathrm{sq}^{-1}$ & [79] \\
\hline AgNWs Ink & Polyester (PET) & $\approx 20-100$ & $3-7$ & $\approx 10 \Omega \mathrm{sq}^{-1}$ & [83] \\
\hline AgNFs and PtNFs & Silk fabric (SF) & $41.3-99$ & $3-8$ & $25 \Omega \mathrm{sq}^{-1}$ & [84] \\
\hline AgNFs & Silk fibroin (SF) & $\approx 28-106.2$ & $0.5-4.5$ & $12 \Omega \mathrm{sq}^{-1}$ & {$[85]$} \\
\hline AgMFs & - & $27.3-209.4$ & $0-1.6$ & $<0.2 \Omega \mathrm{sq}^{-1}$ & [86] \\
\hline AgFDs & Polystyrene film & $52.3-180<$ & $1-4$ & $0.048 \Omega \mathrm{sq}^{-1}$ & [87] \\
\hline AgNWs & PVA Film & $\approx 45-74$ & $3-5$ & $20 \Omega \mathrm{sq}^{-1}$ & [67] \\
\hline AgNWs & $\begin{array}{c}\text { Polyester (PET) and } \\
\text { polydimethylsiloxane (PDMS) }\end{array}$ & $\approx 30-160$ & $5-25$ & $\approx 0.5 \Omega \mathrm{sq}^{-1}$ & [88] \\
\hline AgNWs & Polydimethylsiloxane (PDMS) & $\approx 50-160$ & $1-2$ & $0.25 \Omega \mathrm{sq}^{-1}$ & [89] \\
\hline CuNWs & Polyurethane (PU) & $46-102$ & $3-7$ & $4.7 \Omega \mathrm{sq}^{-1}$ & [90] \\
\hline Cu-Ni NWs & $\begin{array}{l}\text { Poly (ethylene terephthalate) } \\
\text { (PET) }\end{array}$ & 20-106 & $3-15$ & $300 \Omega \mathrm{sq}^{-1}$ & [91] \\
\hline AgNWs & Elastomer & $\approx 40$ & $0.5-1.0$ & $\approx 0.8 \Omega$ & [66] \\
\hline AgNPs & Cotton fabric & $\approx 34-98$ & $1-5$ & $0.26 \Omega \mathrm{sq}^{-1}$ & [92] \\
\hline AgNW/PEDOT: PSS & Silk yarn & $25-64$ & $2-3$ & $\approx 320 \mathrm{~S} / \mathrm{cm}$ & [93] \\
\hline $\mathrm{CuZr}$ & Metallic glasses & 180 & 7 & $3.8 \Omega_{\mathrm{sq}}^{-1}$ & {$[65]$} \\
\hline AgNWs & Cotton fabric & $\approx 42$ & 1.5 & $2.2 \Omega \mathrm{sq}^{-1}$ & [94] \\
\hline Cu filament & PET-Cu braided fabric & $\approx 89$ & 5 & $2.428 \Omega / \mathrm{m}$ & [95] \\
\hline Stainless steel yarns & Polyester knitting fabric & $\approx 60$ & 12 & - & [54] \\
\hline CuNWs & PET fibres & 57 & 3 & - & [96] \\
\hline Silver-plated yarn & Polyester staple yarn & 4 & 70 & - & [97] \\
\hline Stainless steel & Cotton fabric & $\begin{array}{c}\approx 84 \text { (plain) } \\
\approx 99 \text { (Interlock) }\end{array}$ & 3 & $0.3 \Omega \mathrm{cm}^{-1}$ & [73] \\
\hline Stainless steel, CB & Cotton fabric & $\approx 63$ & 6 & $1.2-12 \mathrm{k} \Omega$ & [98] \\
\hline $\mathrm{Ag}$ & $\begin{array}{l}\text { Cotton-nylon } \\
\text { spandex fabric }\end{array}$ & $\approx 119$ & 10 & $21 \Omega \mathrm{mm}$ & [99] \\
\hline $\mathrm{Ag}$ & Polyamide & 52 & 2.5 & $0.64 \Omega$ & [81] \\
\hline AgNPs & Cotton & $36.5-118.7$ & $0.5-2.0$ & - & [100] \\
\hline CuNWs & Polyamide 6 & 70 & 1.8 & $0.3 \Omega \mathrm{sq}^{-1}$ & [101] \\
\hline
\end{tabular}

Note: AgNWs = silver nanowires; AgNFs = silver nano-fibres; AgFDs = silver micro-fibres; CuNWs = copper nanowires; PEDOT:

PSS = poly(3,4-ethylenedioxythiophene) polystyrene sulfonate; $\mathrm{CB}=$ carbon black; $\mathrm{Cu}=$ copper; $\mathrm{Ag}=$ silver.

\subsection{Conductive Polymer Based Heating Textiles}

It has been found that polymeric composites of non-metals are ideal for generating heat. The benefits of these heating yarns are found, compared with other heating materials, for their low power density, lightweight, temperature homogeneity, and their durability and fineness [102-105]. To prepare conductive composites, PPy, PANi, PTh, etc. polymers are used for coating on yarns by different systems. Polypyrrole (PPy) can be coated by chemical and electrochemical methods on nylon fabric. By the gas combustion method, PPycoated polyester fabric can be obtained where $\mathrm{FeCl} 3$ is used as an oxidizing agent [106,107]. A combination of in situ polymerization and interfacial polymerization method is used 
to coat a thin and compact PPy layer on cotton, silk, wool, and polyester fabric and their temperature can rise to $100{ }^{\circ} \mathrm{C}$ at $6 \mathrm{~V}$ [108]. Wang et al. [109] fabricated highly conductive and hydrophobic textiles that showed an excellent heating performance according to Joule's law and the conductivity of the fabric was $1000 \mathrm{Sm}^{-1}$. In the experiment, silicone-coated MXene sheets that were modified by in situ polymerized polypyrrole (PPy) were deposited onto poly (ethylene terephthalate) textiles. Joule heating performances, current-voltage behaviour and temperature stability of silicone-coated M-textile and the SEM images of G/CNC-coated bamboo viscose fabrics are displayed in Figure 5.

Studies show that integrating PPy into fibres, both natural and regenerated, to form a textile composite and also cotton woven fabrics is appropriate for heat creation $[110,111]$. Sparavigna et al. and Macasaquit and Bina recommended that 100\% PPy-coated polyester fabrics are basically functional for large extent purposes, together with medical or other applications among flexible, portable, surface-heating elements [112,113]. There is fair conductivity in PPy-coated polyester-Lycra woven composite fabrics, and efficient heat generation [114,115]. The rate of temperature change has two separate phases for all these composites, an initial sharp rise followed by a leveling-off to plateau, close to PPycoated cotton composites [116]. It has been noted that the doping anion controls the heat and resistivity outcome of PPy composites [117]. By chronological HTHP chemical and electro-chemical polymerizations, nylon fabric with PPy coating is structured. By using a marketable battery of $3.6 \mathrm{~V}$, the surface temperature of this fabric goes up rapidly to around $55^{\circ} \mathrm{C}$ in $2 \mathrm{~min}$ and it is constant for at least ten rounds [106]. There is rational electrical stability in a PPy-coated e-glass fabric, and it is found to be efficient in generating heat. The surface temperature increases by applying an unvarying voltage through the cloth, while power consumption is found to be decreased [118]. For heat generation, PPycoated silk composites are also arranged $[119,120]$. The application of voltage increases the temperature of the PPy-coated woven and non-woven fabrics and studies show the rate of increasing temperature increases exponentially. It is also noticed that the time duration of applying voltage is an important factor for increasing the temperature of the fabrics [121].

The polymer of 3, 4-ethylene dioxophene monomer (EDOT) is called polyethylene dioxophene thiophene (PEDOT). PEDOT has been used for fabricating conductive heating textiles due to its features of high conductivity, simple molecular design, and compact energy gap. In order to synthesize PEDOT with the substrate material, several techniques are used such as spraying, impregnation coating, in situ polymerization, and vapor phase polymerization. To manufacture conductive PET, Yang et al. [122] coated PET with PEDOT film applying the vapor phase polymerization process. Research shows better reusing stability and uniform thermal distribution of AgNWs/PEDOT: PSS composite film by studying its thermal response features on the basis of thermodynamic analysis, the heat capacity of substrate material [123]. The summary of polymer-coated heating textiles is stated in Table 4. 

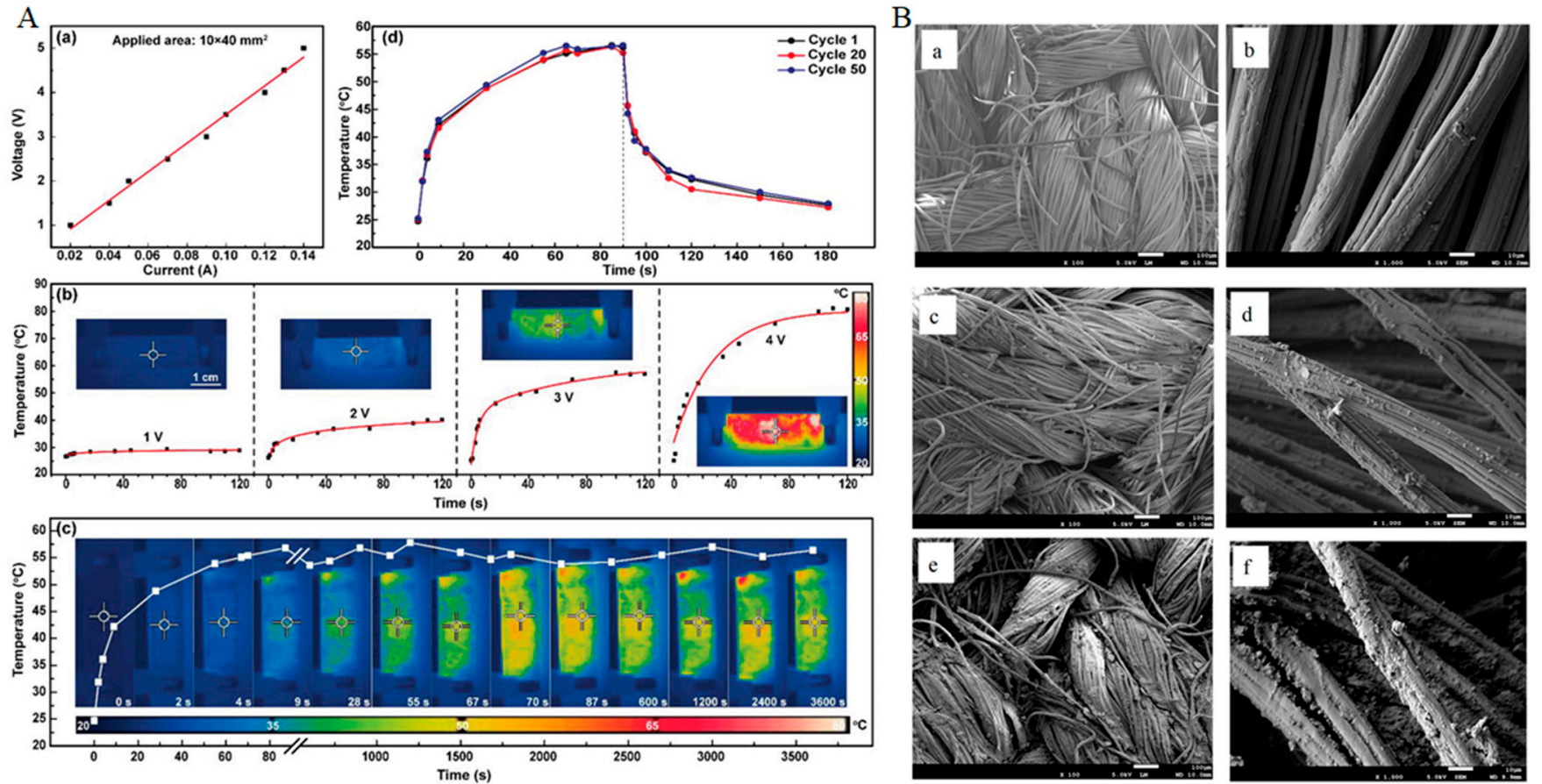

Figure 5. (A). I-V curve and (b) Joule heating performances of silicone-coated M-textile. (c) Time-temperature curve at a constant voltage of $3 \mathrm{~V}$ for silicone-coated M-textile. (d) Temperature stability of the silicone-coated M-textile in heating/cooling cycles [109]; (B). SEM images of CBPFs and GCBPFs ((a,b) CNC-coated bamboo pulp fabric; (c,d) G/CNCcoated fabric with lowest thermal conductivity; (e,f) G/CNC-coated fabric with highest thermal conductivity) [124].

Table 4. Summary of polymer-coated heating textile.

\begin{tabular}{|c|c|c|c|c|c|}
\hline Electroactive Materials & Type of Textile & $\begin{array}{l}\text { Temperature } \\
\text { Range }\left({ }^{\circ} \mathrm{C}\right)\end{array}$ & $\begin{array}{l}\text { Voltage Range } \\
\text { (V) }\end{array}$ & $\begin{array}{l}\text { Electrical } \\
\text { Properties }\end{array}$ & Refs. \\
\hline PEDOT: PSS, rGO & Cotton fabric & 70 & 30 & $150 \Omega \mathrm{sq}^{-1}$ & [125] \\
\hline PEDOT, MXene & Cotton fabric & $\approx 193$ & 12 & $3.6 \Omega \mathrm{sq}^{-1}$ & [126] \\
\hline PPy, $\mathrm{FeCl} 3$ & Cotton fabric & $\approx 168$ & 5 & $0.37 \Omega \mathrm{cm}$ & [127] \\
\hline PPy & PET fabric & $\approx 110$ & 30 & $1434.12 \Omega \mathrm{sq}^{-1}$ & [121] \\
\hline PPy & Cotton fabric & $\approx 48$ & 9 & $32 \Omega \mathrm{sq}^{-1}$ & [128] \\
\hline PPy, MXene, silicone & PET fabric & $\approx 57$ & 3 & $\approx 1000 \mathrm{~S} \mathrm{~m}^{-1}$ & [109] \\
\hline PPy & PET-lycra fabric & $\approx 40$ & 24 & $150-500 \Omega \mathrm{sq}^{-1}$ & [115] \\
\hline Polypyrrole & Nylon fabric & 55 & 3.6 & $5 \Omega \mathrm{sq}^{-1}$ & [107] \\
\hline $\begin{array}{l}\text { Polyethylene dioxophene } \\
\text { thiophene }\end{array}$ & PET & 43 & 15 & $52 \Omega \mathrm{sq}^{-1}$ & [129] \\
\hline PEDOT & Cotton fabric & $\approx 44$ & 6 & $41 \Omega \mathrm{sq}^{-1}$ & [130] \\
\hline PEDOT: PSS, SDS & Cotton fabric & $\approx 99$ & 12 & $1335 \mathrm{Scm}^{-1}$ & [131] \\
\hline PEDOT: PSS, glycerol & Polyamide fabric & $\approx 80$ & 12 & $740 \Omega$ & [129] \\
\hline $\mathrm{rGO}$ & PET/PU fabric & $\approx 59$ & 30 & $2.0 \times 10^{-5} \mathrm{~S} \mathrm{sq}^{-1}$ & [132] \\
\hline rGO & PET fabric & $\approx 138$ & 14 & $24.7 \Omega \mathrm{sq}^{-1}$ & [133] \\
\hline
\end{tabular}

Note: PPy = polypyrrole; PEDOT: PSS = poly(3,4-ethylenedioxythiophene) polystyrene sulfonate; GO = graphene oxide; rGO = reduced graphene oxide. 


\subsection{Carbon Based Heating Textiles}

Conductive materials based on carbon are a good source of heat generation. Graphene, graphite powder, and CNTs are normally attached to the surface of the fibre to make it conductive. By using recycled carbon fibre and dipping and coating CNTs with cotton fabric, where SWCNTs are used as a dispersant, the conductive heating textile can be developed $[134,135]$. To enhance the thermal properties of the fabric, MWCNTs are coated on the cotton fabric through the techniques of impregnation-drying coating and the improvement of thermal conductivity is found [136]. Time-temperature curves for different voltage and temperature stability of flexible MXene-decorated fabric with interwoven conductive networks for integrated Joule heater are shown in Figure 6. For heat generation application, reduced graphene oxide ( $\mathrm{rGO}$ ) nanosheet-coated cotton fabric-based films are used to fabricate electrically conductive textile [137]. Wearable electronics, specific devices for personal cooling and heating, or simply personal thermal management (PTM) devices can be developed by embedding graphene in fabrics. Using highly conductive graphene fibre with superior heating at reduced energy can readily increase stretchability and breathability [138-140]. Surface temperature of triple- and quadruple-layers at various applied voltages and IR images of graphene/polymer coated textile based multi-layer fabric heating element with aramid fabric are shown in Figure 7 . The summary of carbon based heating textile is demonstrated in Table 5.
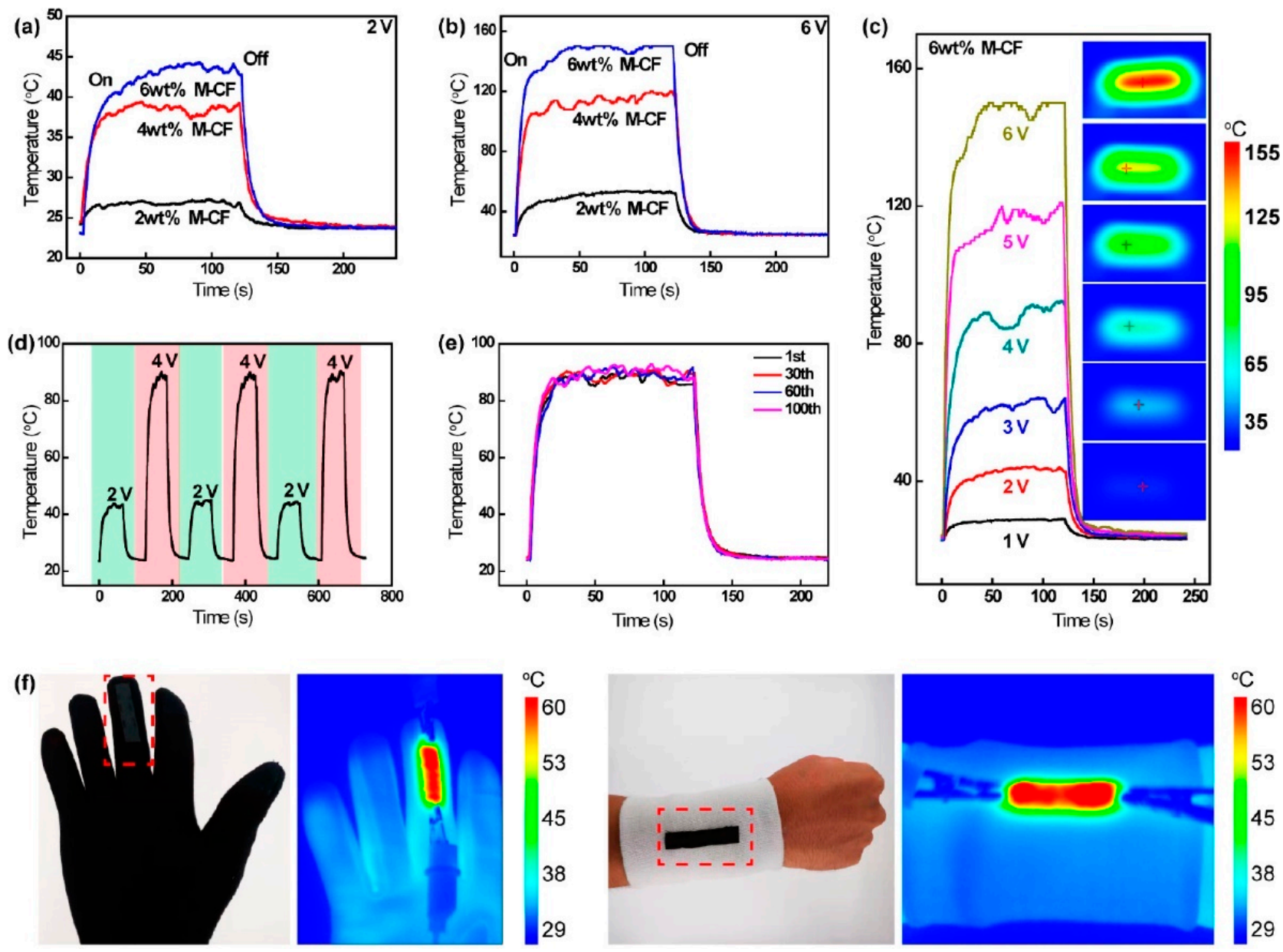

Figure 6. A piece of flexible MXene-decorated fabric with interwoven conductive networks for integrated Joule heating, electromagnetic interference shielding and strain sensing performances: Time-temperature curves of M-C fabrics at a voltage of (a) 2 and (b) $6 \mathrm{~V}$. (c) Time-temperature curves of $6 \mathrm{wt} \% \mathrm{M}$-CF from 1 to $6 \mathrm{~V}$. (d) Temperature adjustability of the $6 \mathrm{wt} \%$ M-CF heater. (e) Temperature stability of $6 \mathrm{wt} \% \mathrm{M}-\mathrm{CF}$ heater under 100 heating cycles. (f) Temperature distribution of the wearable $6 \mathrm{wt} \% \mathrm{M}-\mathrm{CF}$ heater attached on a glove and wrist [141]. 
(a)

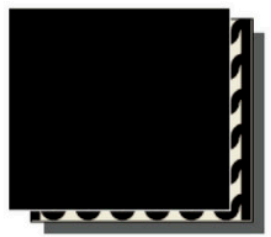

(b)

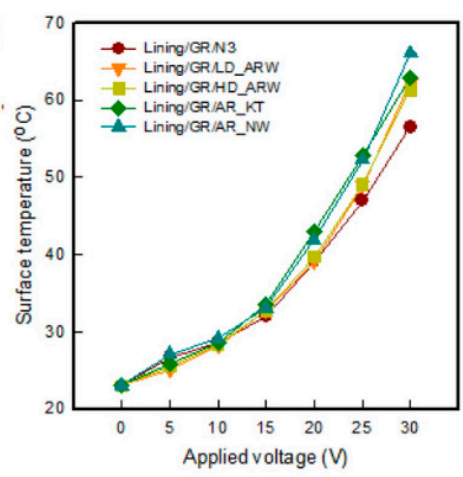

Lining/GR/Outer

(d)

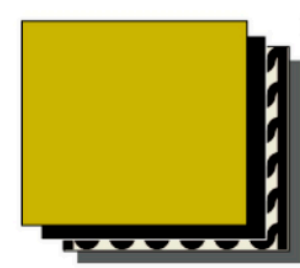

Lining/GR/Filler/Outer (e)

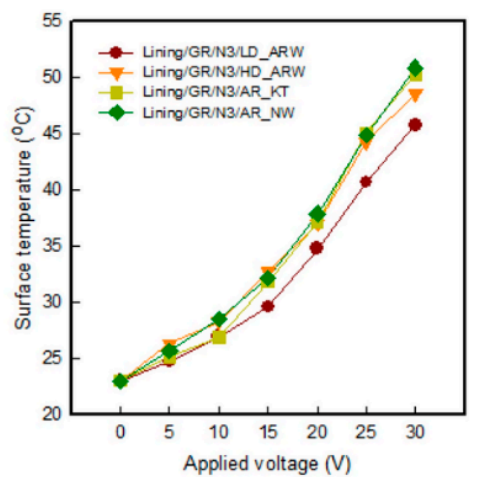

(c)

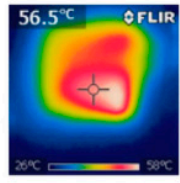

Lining/GR/N3

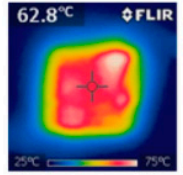

Lining/GR/AR_KT
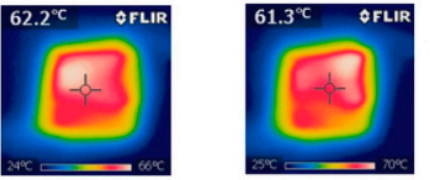

Lining/GR/LD_ARW Lining/GR/HD_ARW

(f)
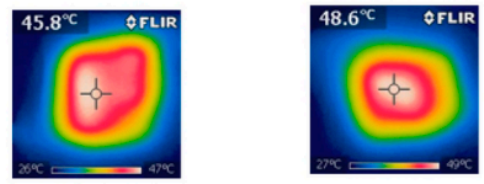

Lining/GR/N3/LD_ARW Lining/GR/N3/HD_ARW
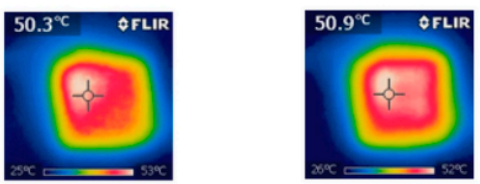

Lining/GR/N3/AR_KT Lining/GR/N3/AR_NW

Figure 7. Thermal insulation property of graphene-/polymer-coated textile-based multi-layer fabric heating element with aramid fabric: (a,d) measuring layer of triple- and quadruple-layer samples. (b,e) surface temperature of triple- and quadruple-layers of samples with various applied voltages, and (c,f) IR images of each sample at $30 \mathrm{~V}$ [142].

Table 5. Summary of carbonaceous heating textile.

\begin{tabular}{|c|c|c|c|c|c|}
\hline Electroactive Materials & Type of Textile & $\begin{array}{c}\text { Temperature Range } \\
\left({ }^{\circ} \mathrm{C}\right)\end{array}$ & $\begin{array}{l}\text { Voltage } \\
\text { Range (V) }\end{array}$ & Electrical Properties & Refs. \\
\hline rGO/PEDOT: PSS & Cotton fabric & $30-70$ & $5-30$ & $150 \Omega \mathrm{sq}^{-1}$ & [125] \\
\hline MWCNT & $\begin{array}{l}\text { Glass or poly(dimethylsiloxane) } \\
\text { (PDMS) }\end{array}$ & 100 & 40 & $172 \Omega \mathrm{sq}^{-1}$ & [143] \\
\hline MWCNTs & Cotton & $\approx 90$ & $10-60$ & $1670 \Omega \mathrm{sq}^{-1}$ & [144] \\
\hline MWCNTs & Silk Fabric & $\approx 49.1$ & $5-25$ & $468 \Omega \mathrm{sq}^{-1}$ & [145] \\
\hline Graphene & Polyimide & $55-150$ & $30-60$ & $1.568 \Omega \mathrm{sq}^{-1}$ & [146] \\
\hline rGO & Polyester fabric & $50-138.64$ & $6-14$ & $24.7 \Omega \mathrm{sq}^{-1}$ & [133] \\
\hline $\mathrm{CB}$ & Polyester Fabric & $\approx 30-85$ & $0-20$ & $<71 \Omega \mathrm{cm}^{-1}$ & [147] \\
\hline $\mathrm{CNT}$ & Cotton Yarn & Max. 80 & $2-5$ & $3.92 \Omega \mathrm{cm}^{-1}$ & [148] \\
\hline $\mathrm{CC} / \mathrm{PW}$ & Thermoplastic Polyurethane (TPU) & $\approx 32.5-50$ & $2-3$ & $374 \mathrm{Sm}^{-1}$ & [149] \\
\hline $\mathrm{MnO} 2 / \mathrm{rGO}$ & Cotton fabric & Max. 36 & $1-15$ & $0.78 \Omega$ & [150] \\
\hline Graphene/WPU & Polyester & 71.3 & 50 & $5.43 \times 10^{3} \Omega \mathrm{sq}^{-1}$ & [151] \\
\hline Recycled carbon fibre & non-woven fabric & 94.6 & 13 & $2.8 \times 10^{3} \mathrm{Sm}^{-1}$ & [152] \\
\hline Graphene, WPU & Aramid fabric (knit) & $\approx 54$ & 5 & $\approx 56 \Omega$ & [153] \\
\hline Graphene, MWCNTs & Cotton & 66.2 & 27 & $29.8 \Omega \mathrm{sq}^{-1}$ & [154] \\
\hline MWCNTs & Polyester/polyurethane & 56.1 & 5 & $2.66 \Omega \mathrm{cm}$ & [155] \\
\hline
\end{tabular}

Note: PEDOT: PSS = poly(3,4-ethylenedioxythiophene) polystyrene sulfonate; $\mathrm{CB}=$ carbon black; $\mathrm{CNT}=$ carbon nanotube; $\mathrm{GO}=$ graphene oxide; $\mathrm{rGO}=$ reduced graphene oxide; $\mathrm{MWCNT}=$ multi-walled carbon nanotube; $\mathrm{WPU}=$ waterborne polyurethane. 
Wearable thermoelectric devices have the potential to generate electricity for onbody applications in a ubiquitous, non-intermittent, and noiseless manner. Due to its out-of-plane thermoelectric generation and strong structural conformability with fabrics, three-dimensional thermoelectric textiles (TETs) outperform other varieties in smart textiles [156-161]. Yuanyuan et al. [157] sewed carbon nanotube yarn-based segmented thermoelectric textiles on a large scale to create organic spacer fabric shaped TETs. It was discovered through a combination of finite element analysis and experimental evaluation that the fabric structure has a substantial impact on power generation. The properly constructed TET has a high output power density and is wearable and stable. Another study generated a stretchable heating carbon nanotube (CNT) fibre with good mechanical and heating capabilities based on the hierarchically helical structure of traditional thermal insulation material-wool [159]. A huge number of generated hierarchically helical voids inside and out provide good thermal insulation. It has a rapid thermal response of over $1000{ }^{\circ} \mathrm{C} \mathrm{s}^{-1}$, a low working voltage of a few volts, and great heating stability over 5000 cycles, to name a few features. Active thermoregulation via electro-heat and thermoelectrics is illustrated in Figure 8. The applications of fibres and yarns in smart fabrics along with conductive features are mentioned in Table 6 and the coating techniques of textile yarn with intrinsically conducting polymer (ICP) are stated in Table 7.

Table 6. Application of fibres and yarns along with conductive features in smart fabrics.

\begin{tabular}{|c|c|c|c|c|c|c|}
\hline Material & $\begin{array}{l}\text { Mesh or } \\
\text { Core }\end{array}$ & Characteristics & Advantage & Disadvantage & $\begin{array}{l}\text { Resistance per Unit } \\
\text { Length }\end{array}$ & Refs. \\
\hline $\begin{array}{c}\text { Copper } \\
\text { wire/tinsel } \\
\text { wire }\end{array}$ & $\begin{array}{l}\text { Polyester, } \\
\text { copper } \\
\text { (tinsel) }\end{array}$ & $\begin{array}{c}\text { Flattened and } \\
\text { twisted with } \\
\text { cotton, nylon, } \\
\text { Nomex or Kevlar } \\
\text { thread }\end{array}$ & $\begin{array}{l}\text { Robust connection, } \\
\text { conventional }\end{array}$ & $\begin{array}{l}\text { Difficult to } \\
\text { integrate into } \\
\text { clothing }\end{array}$ & $\sim 21 \Omega \mathrm{cm}^{-1}$ & [162] \\
\hline $\begin{array}{l}\text { Stainless steel } \\
\text { staple fibres }\end{array}$ & $\begin{array}{l}\text { Blended with } \\
\text { polyester }\end{array}$ & $\begin{array}{l}\text { Composite broken } \\
\text { bundles (sewable) }\end{array}$ & $\begin{array}{c}\text { Strength, resistance to } \\
\text { corrosion, } \\
\text { biologicalinertness }\end{array}$ & $\begin{array}{l}\text { Difficult to attach } \\
\text { to existing } \\
\text { electronics } \\
\text { components }\end{array}$ & $\begin{array}{c}\text { BK } 50 / 2 \sim 50 \Omega \mathrm{cm}^{-1} \\
\text { broken) }\end{array}$ & [47] \\
\hline $\begin{array}{l}\text { Aracon MCAF } \\
\text { metal clad } \\
\text { aramid } \\
\text { (polymer) fibres }\end{array}$ & Kevlar & $\begin{array}{c}\text { Composite core: } \\
\text { Kevlar cladding } \\
\text { metal: } \mathrm{Ag}, \mathrm{Ni}, \mathrm{Cu}, \\
\mathrm{Au}, \mathrm{Sn}(24-200 \text { fibres })\end{array}$ & $\begin{array}{l}\text { Light, flexible, stable, } \\
\text { high temp resistance } \\
\text { Can be soldered like } \\
\text { normal wire }\end{array}$ & $\begin{array}{l}\text { Conformability in } \\
\text { integration with } \\
\text { fabrics }\end{array}$ & $\sim 0.001 \Omega \mathrm{cm}^{-1}$ & [47] \\
\hline $\begin{array}{l}\text { Metallic } \\
\text { organza }\end{array}$ & Cloth & $\begin{array}{c}\text { Composite fibre: } \\
\text { Ag }\end{array}$ & Yarn level integration & $\begin{array}{c}\text { Challenging } \\
\text { connections to data } \\
\text { acquisition }\end{array}$ & $\sim 10 \Omega \mathrm{m}^{-1}$ & [47] \\
\hline Silver thread & Fabric & $\begin{array}{l}\text { Composite2 } \\
\text { ply } \\
\text { Ag fibre, nylon }\end{array}$ & Machine sewable & $\begin{array}{l}\text { Sensitive to } \\
\text { humidity and } \\
\text { aging }\end{array}$ & $\sim 85 \Omega \mathrm{ft}^{-1}$ & [163] \\
\hline $\begin{array}{l}\text { Strips of } \\
\text { conductive } \\
\text { fabric }\end{array}$ & $\begin{array}{l}\text { Coated } \\
\text { or intr. } \\
\text { conductive } \\
\text { fabric }\end{array}$ & $\begin{array}{c}\text { Carbon based, PPy, } \\
\text { PEDOT, PANi, } \\
\text { metal plated } \\
\text { (i.e., } \\
\text { Cu, Ni) }\end{array}$ & $\begin{array}{l}\text { Can be glued, sewed } \\
\text { to other fabrics }\end{array}$ & $\begin{array}{l}\text { Compatibility } \\
\text { and specialty of } \\
\text { connectors }\end{array}$ & Varies & [164] \\
\hline $\begin{array}{c}\text { Thin Kapton } \\
\text { sheet }\end{array}$ & Kapton & $\begin{array}{c}\text { Stacking of } \\
\text { thin film layers } \\
\text { including silicon } \\
\text { nitride }\end{array}$ & $\begin{array}{c}\text { Enables flexible } \\
\text { electronics techniques }\end{array}$ & $\begin{array}{c}\text { Cannot be machine } \\
\text { sewn }\end{array}$ & Varies & [165] \\
\hline
\end{tabular}


a

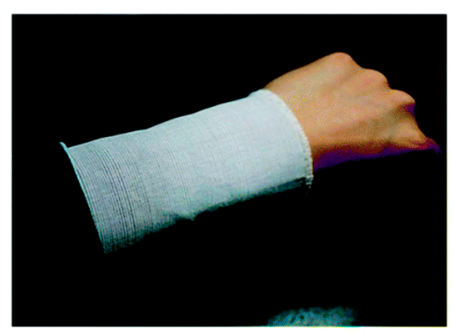

Electroheat heating

C

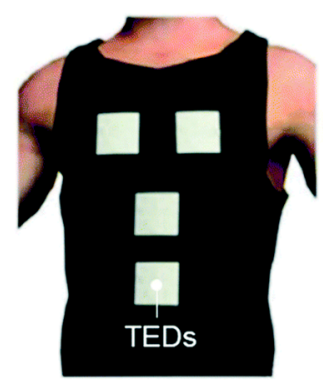

Thermoelectric

textile

f

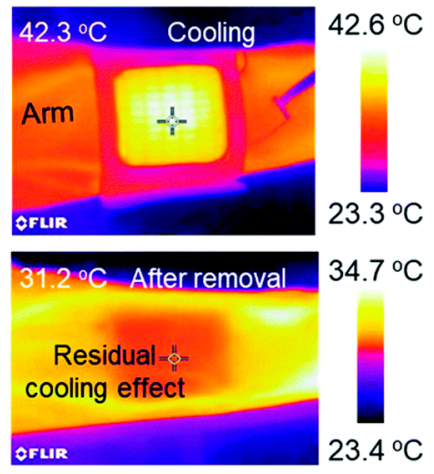

d

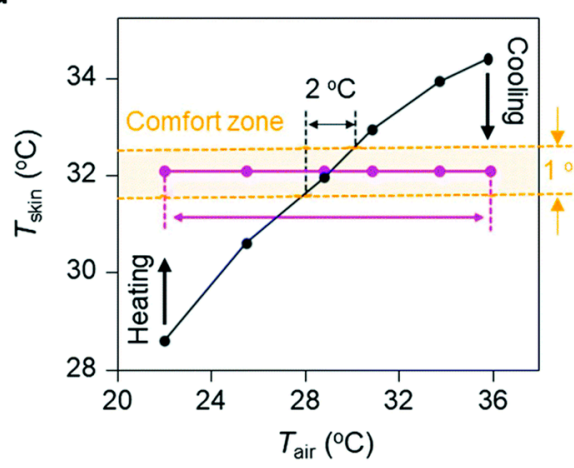

g

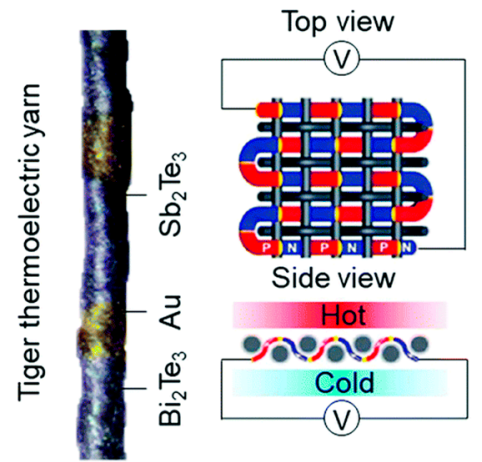

b

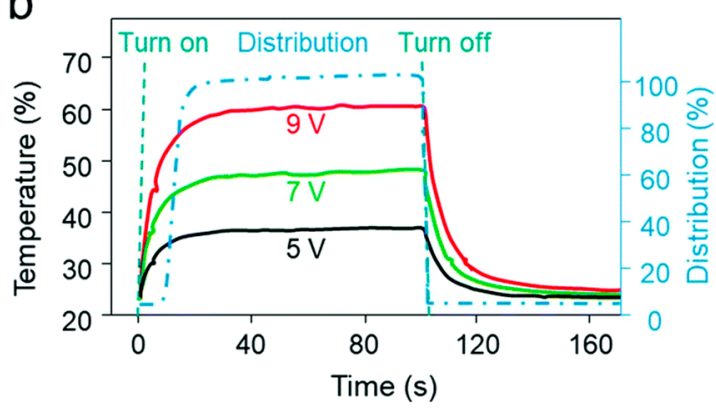

e

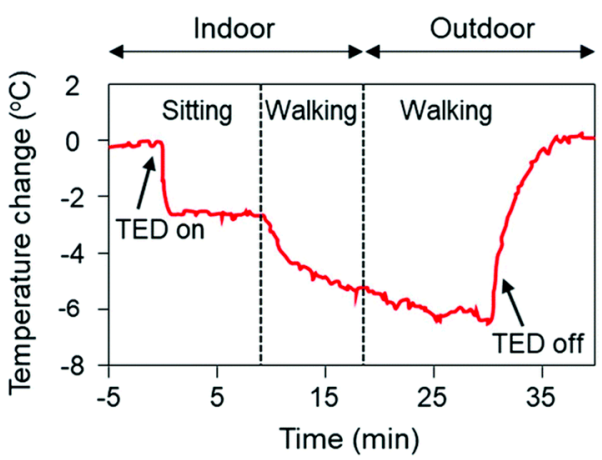

h

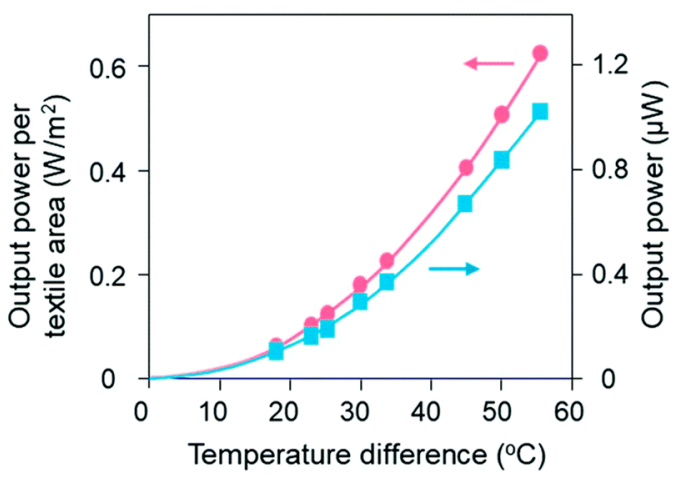

Figure 8. Active thermoregulation via electro-heat and thermoelectrics. (a) Photograph and IR image of a stretchable and energy-efficient smart Joule-heating textile. (b) Temperature and distribution profiles of the smart heating textile. (c) Smart textile with wearable thermoelectric devices (TEDs). (d) Skin temperature as a function of air temperature with a TED-based smart textile. (e) Skin temperature regulation via a TED-based smart textile under daily conditions. (f) IR image of a TED-based smart textile on and off the skin for temperature regulation. (g) Thermoelectric yarn and woven textiles for thermoregulation. (h) Output power of the plain-weave thermoelectric smart textile [156].

Table 7. Coating techniques of textile yarn with ICP.

\begin{tabular}{ccccc}
\hline Coating Technique & Textile Yarn & ICP & $\begin{array}{c}\text { Linear Resistivity } \\
\text { (Conductivity) }\end{array}$ & Refs. \\
\hline $\begin{array}{c}\text { Solution } \\
\text { polymerization }\end{array}$ & Wool, cotton, nylon, and polyester & PANI & $\begin{array}{c}23 \mathrm{k} \Omega / \mathrm{cm} / \\
\text { filament }\end{array}$ & {$[166]$} \\
\hline Dipping and drying & PET & PANI & $\sim 70 \Omega / \mathrm{cm}$ & {$[11]$} \\
\hline Dipping and drying & PET & PANI & $\sim 100 \Omega / \mathrm{cm}$ & {$[42]$} \\
\hline $\begin{array}{c}\text { Solution } \\
\text { polymerization }\end{array}$ & Wool & PPy & $4.8 \mathrm{k} \Omega / \mathrm{cm}$ & {$[167]$} \\
\hline
\end{tabular}


Table 7. Cont.

\begin{tabular}{|c|c|c|c|c|}
\hline Coating Technique & Textile Yarn & ICP & $\begin{array}{l}\text { Linear Resistivity } \\
\text { (Conductivity) }\end{array}$ & Refs. \\
\hline $\begin{array}{c}\text { Solution } \\
\text { polymerization }\end{array}$ & Wool & PPy & $\sim 50 \Omega / \mathrm{cm}$ & [168] \\
\hline Vapour polymerization & $\begin{array}{l}\text { Wool, cotton, } \\
\text { and nylon }\end{array}$ & PPy & $0.37-3 \mathrm{k} \Omega / \mathrm{mm}$ & [169] \\
\hline Vapour polymerization & Wool & PPy & $0.43 \mathrm{k} \Omega / \mathrm{mm}$ & [170] \\
\hline Vapour polymerization & Nylon-6 and polyurethane & PPy & - & [171] \\
\hline $\begin{array}{l}\text { Vapour polymerization } \\
\text { and solution } \\
\text { polymerization }\end{array}$ & $\begin{array}{l}\text { Cotton and } \\
\text { silk }\end{array}$ & PPy & $\begin{array}{l}6.4 \times 10^{-4} \mathrm{~S} / \mathrm{cm} \\
\quad(\text { cotton}) \\
3.2 \times 10^{-4} \mathrm{~S} / \mathrm{cm} \\
\quad(\text { silk })\end{array}$ & [172] \\
\hline Dipping and drying & Silk & PEDOT: PSS & $8.5 \mathrm{~S} / \mathrm{cm}$ & [173] \\
\hline Dipping and drying & Silk & PEDOT: PSS & $2 \mathrm{k} \Omega / \mathrm{mm}$ & [34] \\
\hline Vapour polymerization & Viscose & PEDOT: PSS & - & [35] \\
\hline
\end{tabular}

Note: PANI = polyaniline; $\mathrm{PPy}$ = polypyrrole; PEDOT: PSS = poly(3,4-ethylenedioxythiophene) polystyrene sulfonate.

\section{Future Perspective and Conclusions}

In antiquity, conductive threads were fabricated before the discovery of electricity. With the passage of time, things change, and different innovations are carried out day by day to improve the path of conductivity in textile. Textile fibres, yarns, and fabrics are modified by using metal in the form of wires, coats, wraps, and conductive polymers intrinsically. Traditional electrical wires were initially used, but more advanced methods were then introduced. Particularly with the high expansion in wearable and electronic materials, there will be an additional drive for the enlargement of conducting paths with properties more compatible with traditional fibrous materials. Smart textiles and their applications will boom in the forthcoming in the area of textiles, electronics, and information technology with the development of advanced materials and polymers. The future possibilities for conductive material comprise health, protection, fashion, and fitness. The smart conductive textile can give protection to the firefighters and can monitor health in clinical application, use in sportswear for fitness purposes, functional clothing for fashion and non-clothing are applied for the automotive and home textile purpose.

Textile-based Joule heaters by implementing a combination of nanomaterials, fabrication tactics, and structural designs have changed the paradigm of futuristic intelligent garments and clothing systems. Structural textiles have different benefits over rigid electrical elements such as comfort, feasibility, flexibility, breathability, etc. in designing thermo-regulating devices. In spite of immense progress in textile-based Joule heaters, there still remain some challenges to overcome. It is very difficult to retain the electrical properties or constant heating functionality under mechanical deformations and wet conditions (e.g., wash/sweating). Wearable textile heaters with insufficient durability under critical environments make the acceptability of numerous prototypes questionable for large-scale applications. To keep the electrical functionality activated from creasing or washing stresses, a strong interfacial bonding (intimate contact between textiles and embedding materials) is essential. Moreover, the implementation of flexible encapsulant materials such as 3D printing bundle, fully biobased film, and ultrathin White-EVA films are expected to guarantee a promising bright future for textile-based thermoregulation in the coming decade.

Textile-based heaters open new opportunities for next-generation smart heating devices. Furthermore, problems coexist with conveniences, necessitating increased study and improved tactics to impart higher functionality, wearability, aesthetics, and washability into a textile heating device while maintaining adequate mechanical compliances. Various 
important understandings are still to be uncovered in order to convey the true impact of these wearable textile heaters to our society and to accelerate their large-scale production. We believe that with the continued hard work of researchers from many areas, the design, functionalities, and performance of heating textiles will be enhanced, thereby promoting the development of heating textiles toward a future.

Author Contributions: Conceptualization, M.R.R. and D.M.; methodology, M.R.R. and D.M.; software, M.R.R. and D.M.; validation, M.R.R. and D.M.; formal analysis, M.R.R. and D.M.; investigation, M.R.R. and D.M.; resources, D.M.; data curation, M.R.R. and D.M.; writing—original draft preparation, M.R.R. and D.M.; writing—review and editing, M.R.R. and D.M.; visualization, M.R.R. and D.M.; supervision, D.M.; project administration, D.M. All authors have read and agreed to the published version of the manuscript.

Funding: This paper received no external funding.

Institutional Review Board Statement: Not applicable.

Informed Consent Statement: Not applicable.

Data Availability Statement: Data Sharing is not applicable.

Conflicts of Interest: The authors declare no conflict of interest.

\section{References}

1. Xue, P.; Tao, X.; Leung, M.Y.; Zhang, H. Electromechanical properties of conductive fibres, yarns and fabrics. Wearable Electron. Photonics 2005, 81, 104. [CrossRef]

2. Mattmann, C.; Clemens, F.; Tröster, G. Sensor for measuring strain in textile. Sensors 2008, 8, 3719-3732. [CrossRef]

3. Tang, S.L.P.; Stylios, G.K. An overview of smart technologies for clothing design and engineering. Int. J. Cloth. Sci. Technol. 2006, 18, 108-128. [CrossRef]

4. Schwarz, A.; Kazani, I.; Cuny, L.; Hertleer, C.; Ghekiere, F.; de Clercq, G.; Van Langenhove, L. Comparative study on the mechanical properties of elastic, electro-conductive hybrid yarns and their input materials. Text. Res. J. 2011, 81, 1713-1723. [CrossRef]

5. Hufenbach, W.; Adam, F.; Fischer, W.J; Kunadt, A.; Weck, D. Mechanical behaviour of textile-reinforced thermoplastics with integrated sensor network components. Mater. Des. 2011, 32, 4931-4935. [CrossRef]

6. Jocic, D. Smart Textile Materials by Surface Modification with Biopolymeric Systems. Res. J. Text. Appar. 2008, 12, $58-65$. [CrossRef]

7. Zhang, X.X.; Tao, X. Smart textiles (1): Passive smart. Text. Asia 2001, 32, 45-48.

8. Zhang, X.X.; Tao, X. Smart textiles (2): Active smart. Text. Asia 2001, 32, 49-52.

9. Zhang, X.X.; Tao, X. Smart textiles (3): Very smart. Text. Asia 2001, 32, 35-37.

10. Stoppa, M.; Chiolerio, A. Wearable electronics and smart textiles: A critical review. Sensors 2014, 14, 11957-11992. [CrossRef] [PubMed]

11. Kim, B.; Koncar, V.; Devaux, E.; Dufour, C.; Viallier, P. Electrical and morphological properties of PP and PET conductive polymer fibers. Synth. Met. 2004, 146, 167-174. [CrossRef]

12. Knittel, D.; Schollmeyer, E. Electrically high-conductive textiles. Synth. Met. 2009, 159, 1433-1437. [CrossRef]

13. Wang, H.; Zhou, H.; Gestos, A.; Fang, J.; Niu, H.; Ding, J.; Lin, T. Robust, electro-conductive, self-healing superamphiphobic fabric prepared by one-step vapour-phase polymerisation of poly(3,4-ethylenedioxythiophene) in the presence of fluorinated decyl polyhedral oligomeric silsesquioxane and fluorinated alkyl silane. Soft Matter 2013, 9, 277-282. [CrossRef]

14. Perumalraj, R.; Dasaradan, B.S.; Anbarasu, R.; Arokiaraj, P.; Leo Harish, S. Electromagnetic shielding effectiveness of copper core-woven fabrics. J. Text. Inst. 2009, 100, 512-524. [CrossRef]

15. Roh, J.S.; Chi, Y.S.; Kang, T.J.; Nam, S.W. Electromagnetic Shielding Effectiveness of Multifunctional Metal Composite Fabrics. Text. Res. J. 2008, 78, 825-835. [CrossRef]

16. Palamutcu, S.; Özek, A.; Karpuz, C.; Dağ, N. Electrically conductive textile surfaces and their electromagnetic shielding efficiency measurement. Tekst. Konfeksiyon 2010, 20, 199-207.

17. Özdemir, H.; Özkurt, A. The effects of weave and conductive yarn density on the electromagnetic shielding effectiveness of cellular woven fabrics. Tekst. Konfeksiyon 2013, 23, 124-135.

18. Hwang, P.W.; Chen, A.P.; Lou, C.W.; Lin, J.H. Electromagnetic shielding effectiveness and functions of stainless steel/bamboo charcoal conductive fabrics. J. Ind. Text. 2014, 44, 477-494. [CrossRef]

19. Bhat, N.V.; Seshadri, D.T.; Radhakrishnan, S. Preparation, Characterization, and Performance of Conductive Fabrics: Cotton + PANi. Text. Res. J. 2004, 74, 155-166. [CrossRef]

20. Cork, C.R. Conductive Fibres for Electronic Textiles: An Overview; Elsevier Ltd.: Sawston, Cambridge, UK, 2015. [CrossRef]

21. Mattila, H.R. Intelligent Textiles and Clothing, 2nd ed.; Woodhead Publishing Limited: Sawston, Cambridge, UK, 2006. 
22. Li, L.; Yang, K.; Song, G.; Zhang, L.; Guo, J. Research and Application of the Property of Conductive Knitted Fabrics. Mod. Appl. Sci. 2009, 3, 84-88. [CrossRef]

23. Naghdi, S.; Rhee, K.Y.; Hui, D.; Park, S.J. A review of conductive metal nanomaterials as conductive, transparent, and flexible coatings, thin films, and conductive fillers: Different deposition methods and applications. Coatings 2018, 8, 278. [CrossRef]

24. Balint, R.; Cassidy, N.J.; Cartmell, S.H. Conductive polymers: Towards a smart biomaterial for tissue engineering. Acta Biomater. 2014, 10, 2341-2353. [CrossRef]

25. Meguid, S.A.; Weng, G.J. Micromechanics and Nanomechanics of Composite Solids; Springer: Cham, Switzerland, 2017. [CrossRef]

26. Rothon, R. Sustainable and Recycled Particulate Fillers. In Polymers and Polymeric Composites: A Reference Series; Springer: Berlin, Germany, 2016. [CrossRef]

27. Lund, A.; van der Velden, N.M.; Persson, N.K.; Hamedi, M.M.; Müller, C. Electrically conducting fibres for e-textiles: An open playground for conjugated polymers and carbon nanomaterials. Mater. Sci. Eng. R Rep. 2018, 126, 1-29. [CrossRef]

28. Chatterjee, K.; Tabor, J.; Ghosh, T.K. Electrically conductive coatings for fiber-based E-Textiles. Fibers 2019, 7, 51. [CrossRef]

29. Schmidt, E.; Hasan, M.M.B.; Abdkader, A.; Cherif, C. Development of a process chain for the production of high-performance 100\% metal spun yarns based on planed metal staple fibres. SN Appl. Sci. 2020, 2, 1-17. [CrossRef]

30. Zhang, Y.; Wang, H.; Lu, H.; Li, S.; Zhang, Y. Electronic fibers and textiles: Recent progress and perspective. IScience 2021, 24, 102716. [CrossRef] [PubMed]

31. Song, H.Y.; Lee, J.H.; Kang, D.; Cho, H.; Cho, H.S.; Lee, J.W.; Lee, Y.J. Textile electrodes of jacquard woven fabrics for biosignal measurement. J. Text. Inst. 2010, 101, 758-770. [CrossRef]

32. Schwarz, A.; Cardoen, J.; Westbroek, P.; van Langenhove, L.; Bruneel, E.; van Driessche, I.; Hakuzimana, J. Steps Towards a Textile-Based Transistor: Development of the Gate and Insulating Layer. Text. Res. J. 2010, 80, 1738-1746. [CrossRef]

33. Alagirusamy, R.; Eichhoff, J.; Gries, T.; Jockenhoevel, S. Coating of conductive yarns for electro-textile applications. J. Text. Inst. 2013, 104, 270-277. [CrossRef]

34. Kuhn, H.H.; Child, A.D.; Kimbrell, W.C. Toward real applications of conductive polymers. Synth. Met. 1995, 71, $2139-2142$. [CrossRef]

35. Hamedi, M.; Forchheimer, R.; Inganäs, O. Towards woven logic from organic electronic fibres. Nat. Mater. 2007, 6, 357-362. [CrossRef] [PubMed]

36. Müller, C.; Hamedi, M.; Karlsson, R.; Jansson, R.; Marcilla, R.; Hedhammar, M. Woven electrochemical transistors on silk fibers. Adv. Mater. 2011, 23, 898-901. [CrossRef]

37. Behabtu, N.; Young, C.C.; Tsentalovich, D.E.; Kleinerman, O.; Wang, X.; Ma, A.W.K.; Bengio, E.A.; Waarbeek, R.F.T.; de Jong, J.J.; Hoogerwerf, R.E.; et al. Strong, light, multifunctional fibers of carbon nanotubes with ultrahigh conductivity. Science 2013, 339, 182-186. [CrossRef]

38. Devaux, E.; Koncar, V.; Kim, B.; Campagne, C.; Roux, C.; Rochery, M.; Saihi, D. Processing and characterization of conductive yarns by coating or bulk treatment for smart textile applications. Trans. Inst. Meas. Control. 2007, 29, 355-376. [CrossRef]

39. Mirjalili, M.; Karimi, L. Preparation of melt spun electroconductive fine fibres containing carbon nanotubes. Autex Res. J. 2015, 15, 87-92. [CrossRef]

40. Ye, C.; Dong, S.; Ren, J.; Ling, S. Ultrastable and High-Performance Silk Energy Harvesting Textiles. Nano-Micro Lett. 2020, 12, 1-15. [CrossRef]

41. Locher, I. Technologies for System-On-Textile Integration; Swiss Federal Institute of Technology: Zurich, Switzerland, 2006. [CrossRef]

42. Kim, B.; Koncar, V.; Dufour, C. Polyaniline-coated PET conductive yarns: Study of electrical, mechanical, and electro-mechanical properties. J. Appl. Polym. Sci. 2006, 101, 1252-1256. [CrossRef]

43. Negru, D.; Buda, C.T.; Avram, D. Electrical conductivity of woven fabrics coated with carbon black particles. Fibres Text. East. Eur. 2012, 90, 53-56.

44. Xue, P.; Park, K.H.; Tao, X.M.; Chen, W.; Cheng, X.Y. Electrically conductive yarns based on PVA/carbon nanotubes. Compos. Struct. 2007, 78, 271-277. [CrossRef]

45. Show, Y.; Itabashi, H. Electrically conductive material made from CNT and PTFE. Diam. Relat. Mater. 2008, 17, 602-605. [CrossRef]

46. Gurarslan, A.; Özdemir, B.; Bayat, İ.H.; Yelten, M.B.; Kurt, G.K. Silver nanowire coated knitted wool fabrics for wearable electronic applications. J. Eng. Fibers Fabr. 2019, 14, 1-8. [CrossRef]

47. Russo, P.R.; Gershenfeld, N. E-broidery: Design and fabrication of textile-based computing. IBM Syst. J. 2000, 39, 840-860.

48. Li, Y.; Cheng, X.Y.; Leung, M.Y.; Tsang, J.; Tao, X.M.; Yuen, M.C.W. A flexible strain sensor from polypyrrole-coated fabrics. Synth. Met. 2005, 155, 89-94. [CrossRef]

49. Jiyong, H.; Xiaofeng, Z.; Guohao, L.; Xudong, Y.; Xin, D. Electrical properties of PPy-coated conductive fabrics for human joint motion monitoring. Autex Res. J. 2016, 16, 7-12. [CrossRef]

50. Tokarska, M.; Gniotek, K. Anisotropy of the electrical properties of flat textiles. J. Text. Inst. 2015, 106, 9-18. [CrossRef]

51. Lizák, P.; Mojumdar, S.C. Thermal properties of textile fabrics. J. Therm. Anal. Calorim. 2013, 112, 1095-1100. [CrossRef]

52. Cheng, K.B.; Lee, M.L.; Ramakrishna, S.; Ueng, T.H. Electromagnetic Shielding Effectiveness of Stainless Steel/Polyester Woven Fabrics. Text. Res. J. 2001, 71, 42-49. [CrossRef]

53. Zhang, H.; Tao, X.; Wang, S.; Yu, T. Electro-Mechanical Properties of Knitted Fabric Made From Conductive Multi-Filament Yarn Under Unidirectional Extension. Text. Res. J. 2005, 75, 598-606. [CrossRef]

54. Kayacan, O.; Bulgun, E.Y. Heating behaviors of metallic textile structures. Int. J. Cloth. Sci. Technol. 2009, 21, 127-136. [CrossRef] 
55. Peter, M.; Barrie, J. Industrial and Process Furnaces: Principles, Design and Operation, 2nd ed.; Butterworth-Heinemann Publisher: London, UK, 2014. [CrossRef]

56. Scott, R.A. The technology of electrically heated clothing. Ergonomics 1988, 31, 1065-1081. [CrossRef]

57. Hao, L.; Yi, Z.; Li, C.; Li, X.; Yuxiu, W.; Yan, G. Development and characterization of flexible heating fabric based on conductive filaments, Meas. J. Int. Meas. Confed. 2012, 45, 1855-1865. [CrossRef]

58. Nakad, Z.; Jones, M.; Martin, T.; Shenoy, R. Using electronic textiles to implement an acoustic beamforming array: A case study. Pervasive Mob. Comput. 2007, 3, 581-606. [CrossRef]

59. Power, E.J. Knitting of electroconductive yarns. IEE Eurowearable 2003, 55-60. [CrossRef]

60. Stavrakis, A.K.; Simić, M.; Stojanović, G.M. Electrical characterization of conductive threads for textile electronics. Electronics 2021, 10, 967. [CrossRef]

61. De Rossi, D.; della Santa, A.; Mazzoldi, A. Dressware: Wearable hardware. Mater. Sci. Eng. C 1999, 7, 31-35. [CrossRef]

62. Laforte, J.L.; Louchez, P.; Bouchard, G.; Ma, F. A facility to evaluate performance of aircraft ground de/anti-icing fluids subjected to freezing rain. Cold Reg. Sci. Technol. 1990, 18, 161-171. [CrossRef]

63. Baars, W.J.; Stearman, R.O.; Tinney, C.E. A Review on the Impact of Icing on Aircraft Stability and Control. ASD J. 2010, 2, 35-52. [CrossRef]

64. Lewis, G.K.; Langer, M.D.; Henderson, C.R.; Ortiz, R. Design and evaluation of a wearable self-applied therapeutic ultrasound device for chronic myofascial pain. Ultrasound Med. Biol. 2013, 39, 1429-1439. [CrossRef]

65. An, B.W.; Gwak, E.J.; Kim, K.; Kim, Y.C.; Jang, J.; Kim, J.Y.; Park, J.U. Stretchable, Transparent Electrodes as Wearable Heaters Using Nanotrough Networks of Metallic Glasses with Superior Mechanical Properties and Thermal Stability. Nano Lett. 2016, 16, 471-478. [CrossRef] [PubMed]

66. Choi, S.; Park, J.; Hyun, W.; Kim, J.; Kim, J.; Lee, Y.B.; Song, C.; Hwang, H.J.; Kim, J.H.; Hyeon, T.; et al. Stretchable Heater Using Ligand-Exchanged Silver Nanowire Nanocomposite for Wearable Articular Thermotherapy. ACS Nano 2015, 9, 6626-6633. [CrossRef]

67. Lan, W.; Chen, Y.; Yang, Z.; Han, W.; Zhou, J.; Zhang, Y.; Wang, J.; Tang, G.; Wei, Y.; Dou, W.; et al. Ultraflexible Transparent Film Heater Made of Ag Nanowire/PVA Composite for Rapid-Response Thermotherapy Pads. ACS Appl. Mater. Interfaces 2017, 9 , 6644-6651. [CrossRef] [PubMed]

68. Giansanti, D.; Maccioni, G. Development and testing of a wearable Integrated Thermometer sensor for skin contact thermography. Med. Eng. Phys. 2007, 29, 556-565. [CrossRef]

69. Suh, M.; Curto, S.; Prakash, P.; van Rhoon, G. Wearable Device for Thermotherapies; Elsevier Ltd.: Amsterdam, The Netherlands, 2019. [CrossRef]

70. Adnan, M.; Moses, J.J. A Study on the Efficiency of Lavender Microcapsules on Silk/Lyocell Blended Fabrics. In Functional Textile and Clothing; Springer: Singapore, 2019. [CrossRef]

71. Fang, S.; Wang, R.; Ni, H.; Liu, H.; Liu, L. A review of flexible electric heating element and electric heating garments. J. Ind. Text. 2020, 1-36. [CrossRef]

72. Šahta, I.; Baltina, I.; Truskovska, N.; Blums, J.; Deksnis, E. Selection of conductive yarns for knitting an electrical heating element. WIT Trans. Built Environ. 2014, 137, 91-102. [CrossRef]

73. Hamdani, S.T.A.; Fernando, A.; Maqsood, M. Thermo-mechanical behavior of stainless steel knitted structures. Heat Mass Transf. Stoffuebertragung 2016, 52, 1861-1870. [CrossRef]

74. Hsu, P.C.; Liu, X.; Liu, C.; Xie, X.; Lee, H.R.; Welch, A.J.; Zhao, T.; Cui, Y. Personal thermal management by metallic nanowirecoated textile. Nano Lett. 2015, 15, 365-371. [CrossRef]

75. Atwa, Y.; Maheshwari, N.; Goldthorpe, I.A. Silver nanowire coated threads for electrically conductive textiles. J. Mater. Chem. C 2015, 3, 3908-3912. [CrossRef]

76. Liu, H.; Li, J.; Chen, L.; Liu, L.; Li, Y.; Li, X.; Li, X.; Yang, H. Thermal-electronic behaviors investigation of knitted heating fabrics based on silver plating compound yarns. Text. Res. J. 2016, 86, 1398-1412. [CrossRef]

77. Li, Y.; Liu, H.; Li, X. Thermal-electrical properties and resistance stability of silver coated yarns. AIP Conf. Proc. 2017, 1820, 1-4 [CrossRef]

78. Sun, K.; Liu, S.; Long, H. Structural parameters affecting electrothermal properties of woolen knitted fabrics integrated with silver-coated yarns. Polymers 2019, 11, 1709. [CrossRef]

79. Hong, S.; Lee, H.; Lee, J.; Kwon, J.; Han, S.; Suh, Y.D.; Cho, H.; Shin, J.; Yeo, J.; Ko, S.H. Highly Stretchable and Transparent Metal Nanowire Heater for Wearable Electronics Applications. Adv. Mater. 2015, 27, 4744-4751. [CrossRef]

80. Guo, R.; Wang, H.; Sun, X.; Yao, S.; Chang, H.; Wang, H.; Liu, J.; Zhang, Y. Semiliquid Metal Enabled Highly Conductive Wearable Electronics for Smart Fabrics. ACS Appl. Mater. Interfaces 2019, 11, 30019-30027. [CrossRef] [PubMed]

81. Repon, M.R.; Mikučionienè, D.; Baltina, I.; Blūms, J.; Laureckiene, G. Ag Coated Pa-Based Electro-Conductive Knitted Fabrics for Heat Generation in Compression Supports. Autex Res. J. 2021, 21, 1-9. [CrossRef]

82. Zhao, M.; Li, D.; Huang, J.; Wang, D.; Mensah, A.; Wei, Q. A multifunctional and highly stretchable electronic device based on silver nanowire/wrap yarn composite for a wearable strain sensor and heater. J. Mater. Chem. C 2019, 7, 13468-13476. [CrossRef]

83. Kim, T.; Kim, Y.W.; Lee, H.S.; Kim, H.; Yang, W.S.; Suh, K.S. Uniformly interconnected silver-nanowire networks for transparent film heaters. Adv. Funct. Mater. 2013, 23, 1250-1255. [CrossRef] 
84. Huang, J.; Li, Y.; Xu, Z.; Li, W.; Xu, B.; Meng, H.; Liu, X.; Guo, W. An integrated smart heating control system based on sandwich-structural textiles. Nanotechnology 2019, 30, 325203. [CrossRef]

85. Huang, J.; Xu, Z.; Qiu, W.; Chen, F.; Meng, Z.; Hou, C.; Guo, W.; Liu, X.Y. Stretchable and Heat-Resistant Protein-Based Electronic Skin for Human Thermoregulation. Adv. Funct. Mater. 2020, 30, 1-9. [CrossRef]

86. Kim, Y.I.; An, S.; Kim, M.W.; Jo, H.S.; Kim, T.G.; Swihart, M.T.; Yarin, A.L.; Yoon, S.S. Highly transparent, conducting, bodyattachable metallized fibers as a flexible and stretchable film. J. Alloys Compd. 2019, 790, 1127-1136. [CrossRef]

87. Tian, B.; Liu, Q.; Luo, C.; Feng, Y.; Wu, W. Multifunctional Ultrastretchable Printed Soft Electronic Devices for Wearable Applications. Adv. Electron. Mater. 2020, 6, 1900922. [CrossRef]

88. Cui, Z.; Han, Y.; Huang, Q.; Dong, J.; Zhu, Y. Electrohydrodynamic printing of silver nanowires for flexible and stretchable electronics. Nanoscale 2018, 10, 6806-6811. [CrossRef]

89. Yao, S.; Cui, J.; Cui, Z.; Zhu, Y. Soft electrothermal actuators using silver nanowire heaters. Nanoscale 2017, 9, 3797-3805. [CrossRef]

90. Ding, S.; Jiu, J.; Gao, Y.; Tian, Y.; Araki, T.; Sugahara, T.; Nagao, S.; Nogi, M.; Koga, H.; Suganuma, K.; et al. One-Step Fabrication of Stretchable Copper Nanowire Conductors by a Fast Photonic Sintering Technique and Its Application in Wearable Devices. ACS Appl. Mater. Interfaces 2016, 8, 6190-6199. [CrossRef]

91. Chen, J.; Chen, J.; Li, Y.; Zhou, W.; Feng, X.; Huang, Q.; Zheng, J.G.; Liu, R.; Ma, Y.; Huang, W. Enhanced oxidation-resistant $\mathrm{Cu}-\mathrm{Ni}$ core-shell nanowires: Controllable one-pot synthesis and solution processing to transparent flexible heaters. Nanoscale 2015, 7, 16874-16879. [CrossRef] [PubMed]

92. Niu, B.; Yang, S.; Hua, T.; Tian, X.; Koo, M.K. Facile fabrication of highly conductive, waterproof, and washable e-textiles for wearable applications. Nano Res. 2021, 14, 1043-1052. [CrossRef]

93. Hwang, B.; Lund, A.; Tian, Y.; Darabi, S.; Darabi, S.; Müller, C.; Müller, C. Machine-Washable Conductive Silk Yarns with a Composite Coating of Ag Nanowires and PEDOT:PSS. ACS Appl. Mater. Interfaces 2020, 12, 27537-27544. [CrossRef]

94. Lian, Y.; Yu, H.; Wang, M.; Yang, X.; Li, Z.; Yang, F.; Wang, Y.; Tai, H.; Liao, Y.; Wu, J.; et al. A multifunctional wearable E-textile: Via integrated nanowire-coated fabrics. J. Mater. Chem. C 2020, 8, 8399-8409. [CrossRef]

95. Pragya, A.; Singh, H.; Kumar, B.; Gupta, H.; Shankar, P. Designing and investigation of braided-cum-woven structure for wearable heating textile. Eng. Res. Express 2020, 2, 015003. [CrossRef]

96. Li, X.; Li, Y.; Guan, T.; Xu, F.; Sun, J. Durable, Highly Electrically Conductive Cotton Fabrics with Healable Superamphiphobicity. ACS Appl. Mater. Interfaces 2018, 10, 12042-12050. [CrossRef] [PubMed]

97. Hamdani, S.T.A.; Potluri, P.; Fernando, A. Thermo-mechanical behavior of textile heating fabric based on silver coated polymeric yarn. Materials 2013, 6, 1072-1089. [CrossRef]

98. Erdogan, M.H.; Erdem, N. A theoretical approach for predicting the tensile behavior of needle punched-heat set heavy geotextiles. Ind. Textil 2011, 62, 227-232.

99. Ali, A.; Baheti, V.; Militky, J.; Khan, Z.; Zhu, G. Metal Coating on Ultrafine Polyester Non-woven Fabrics and Their Ageing Properties. Fibers Polym. 2019, 20, 1347-1359. [CrossRef]

100. Guo, Z.; Wang, Y.; Huang, J.; Zhang, S.; Zhang, R.; Ye, D.; Cai, G.; Yang, H.; Gu, S.; Xu, W. Multi-functional and water-resistant conductive silver nanoparticle-decorated cotton textiles with excellent joule heating performances and human motion monitoring. Cellulose 2021, 28, 7483-7495. [CrossRef]

101. Guo, Z.; Sun, C.; Wang, J.; Cai, Z.; Ge, F. High-performance laminated fabric with enhanced photothermal conversion and Joule heating effect for personal thermal management. ACS Appl. Mater. Interfaces 2021, 13, 8851-8862. [CrossRef]

102. Boutrois, J.P.; Jolly, R.; Pétrescu, C. Process of polypyrrole deposit on textile. Product characteristics and applications. Synth. Met. 1997, 85, 1405-1406. [CrossRef]

103. Jolly, R.; Petrescu, C.; Thieblemont, J.C.; Marechal, J.C.; Menneteau, F.D. Heating Panels for Accomodation Obtained from Textiles Made Electrically Conductive by Polypyrrole Deposit. J. Ind. Text. 1994, 23, 228-236. [CrossRef]

104. Ala, O.; Fan, Q. Applications of Conducting Polymers in Electronic Textiles. Res. J. Text. Appar. 2009, 13, 51-68. [CrossRef]

105. Bajgar, V.; Penhaker, M.; Martinková, L.; Pavlovič, A.; Bober, P.; Trchová, M.; Stejskal, J. Cotton fabric coated with conducting polymers and its application in monitoring of carnivorous plant response. Sensors 2016, 16, 498. [CrossRef]

106. Lee, J.Y.; Park, D.W.; Lim, J.O. Polypyrrole-coated woven fabric as a flexible surface-heating element. Macromol. Res. 2003, 11, 481-487. [CrossRef]

107. Shang, S.; Yang, X.; Tao, X.M.; Lam, S.S. Vapor-phase polymerization of pyrrole on flexible substrate at low temperature and its application in heat generation. Polym. Int. 2010, 59, 204-211. [CrossRef]

108. Lv, J.; Zhou, P.; Zhang, L.; Zhong, Y.; Sui, X.; Wang, B.; Chen, Z.; Xu, H.; Mao, Z. High-performance textile electrodes for wearable electronics obtained by an improved in situ polymerization method. Chem. Eng. J. 2019, 361, 897-907. [CrossRef]

109. Wang, Q.W.; Zhang, H.B.; Liu, J.; Zhao, S.; Xie, X.; Liu, L.; Yang, R.; Koratkar, N.; Yu, Z.Z. Multifunctional and Water-Resistant MXene-Decorated Polyester Textiles with Outstanding Electromagnetic Interference Shielding and Joule Heating Performances. Adv. Funct. Mater. 2019, 29, 1-10. [CrossRef]

110. Dall'Acqua, L.; Tonin, C.; Varesano, A.; Canetti, M.; Porzio, W.; Catellani, M. Vapour phase polymerisation of pyrrole on cellulose-based textile substrates. Synth. Met. 2006, 156, 379-386. [CrossRef]

111. Seshadri, D.T.; Bhat, N.V. Synthesis and properties of cotton fabrics modified with polypyrrole. BTRA Scan. 2005, 35, 1-8. [CrossRef] 
112. Yildiz, Z.; Usta, I.; Gungor, A. Electrical properties and electromagnetic shielding effectiveness of polyester yarns with polypyrrole deposition. Text. Res. J. 2012, 82, 2137-2148. [CrossRef]

113. Sparavigna, A.C.; Florio, L.; Avloni, J.; Henn, A. Polypyrrole Coated PET Fabrics for Thermal Applications. Mater. Sci. Appl. 2010, 1, 253-259. [CrossRef]

114. Kaynak, A.; Håkansson, E. Short-term heating tests on doped polypyrrole-coated polyester fabrics. Synth. Met. 2008, 158, 350-354. [CrossRef]

115. Kaynak, A.; Håkansson, E. Generating heat from conducting polypyrrole-coated PET fabrics. Adv. Polym. Technol. 2005, 24, 194-207. [CrossRef]

116. Hakansson, E.; Kaynak, A.; Lin, T.; Nahavandi, S.; Jones, T.; Hu, E. Characterization of conducting polymer coated synthetic fabrics for heat generation. Synth. Met. 2004, 144, 21-28. [CrossRef]

117. Rodriguez, J.; Otero, T.F.; Grande, H.; Moliton, J.P.; Moliton, A.; Trigaud, T. Optimization of the electrical conductivity of polypyrrole films electrogenerated on aluminium electrodes. Synth. Met. 1996, 76, 301-303. [CrossRef]

118. Abbasi, A.M.R.; Militky, J.; Gregr, J. Heat Generation by Polypyrrole Coated Glass Fabric. J. Text. 2013, 2013, 1-5. [CrossRef]

119. Malhotra, U.; Maity, S.; Chatterjee, A. Polypyrrole-silk electro-conductive composite fabric by in situ chemical polymerization. J. Appl. Polym. Sci. 2015, 132, 1-10. [CrossRef]

120. Maráková, N.; Humpolíček, P.; Kašpárková, V.; Capáková, Z.; Martinková, L.; Bober, P.; Trchová, M.; Stejskal, J. Antimicrobial activity and cytotoxicity of cotton fabric coated with conducting polymers, polyaniline or polypyrrole, and with deposited silver nanoparticles. Appl. Surf. Sci. 2017, 396, 169-176. [CrossRef]

121. Maity, S.; Chatterjee, A.; Singh, B.; Singh, A.P. Polypyrrole based electro-conductive textiles for heat generation. J. Text. Inst. 2014, 105, 887-893. [CrossRef]

122. Yang, X.; Shang, S.; Li, L.; Tao, X.M.; Yan, F. Vapor phase polymerization of 3,4-ethylenedioxythiophene on flexible substrate and its application on heat generation. Polym. Adv. Technol. 2011, 22, 1049-1055. [CrossRef]

123. Ji, S.; He, W.; Wang, K.; Ran, Y.; Ye, C. Thermal response of transparent silver nanowire/PEDOT:PSS film heaters. Small 2014, 10, 4951-4960. [CrossRef]

124. Yang, F.; Lan, C.; Zhang, H.; Guan, J.; Zhang, F.; Fei, B.; Zhang, J. Study on graphene/CNC-coated bamboo pulp fabric preparation of fabrics with thermal conductivity. Polymers 2019, 11, 1265. [CrossRef]

125. Ahmed, A.; Jalil, M.A.; Hossain, M.M.; Moniruzzaman, M.; Adak, B.; Islam, M.T.; Parvez, M.S.; Mukhopadhyay, S. A PEDOT:PSS and graphene-clad smart textile-based wearable electronic Joule heater with high thermal stability. J. Mater. Chem. C 2020, 8 , 16204-16215. [CrossRef]

126. Zheng, X.; Shen, J.; Hu, Q.; Nie, W.; Wang, Z.; Zou, L.; Li, C. Vapor phase polymerized conducting polymer/MXene textiles for wearable electronics. Nanoscale 2021, 13, 1832-1841. [CrossRef] [PubMed]

127. Xie, J.; Pan, W.; Guo, Z.; Jiao, S.S.; Yang, L.P. In situ polymerization of polypyrrole on cotton fabrics as flexible electrothermal materials. J. Eng. Fibers Fabr. 2019, 14, 1-8. [CrossRef]

128. Lee, S.; Park, C.H. Electric heated cotton fabrics with durable conductivity and self-cleaning properties. RSC Adv. 2018, 8 , 31008-31018. [CrossRef]

129. Moraes, M.R.; Alves, A.C.; Toptan, F.; Martins, M.S.; Vieira, E.M.F.; Paleo, A.J.; Souto, A.P.; Santos, W.L.F.; Esteves, M.F.; Zille, A. Glycerol/PEDOT:PSS coated woven fabric as a flexible heating element on textiles. J. Mater. Chem. C 2017, 5, 3807-3822. [CrossRef]

130. Zhang, L.; Baima, M.; Andrew, T.L. Transforming Commercial Textiles and Threads into Sewable and Weavable Electric Heaters. ACS Appl. Mater. Interfaces 2017, 9, 32299-32307. [CrossRef]

131. Yeon, C.; Kim, G.; Lim, J.W.; Yun, S.J. Highly conductive PEDOT:PSS treated by sodium dodecyl sulfate for stretchable fabric heaters. RSC Adv. 2017, 7, 5888-5897. [CrossRef]

132. Liu, X.; Qin, Z.; Dou, Z.; Liu, N.; Chen, L.; Zhu, M. Fabricating conductive poly(ethylene terephthalate) nonwoven fabrics using an aqueous dispersion of reduced graphene oxide as a sheet dyestuff. RSC Adv. 2014, 4, 23869-23875. [CrossRef]

133. Wang, D.; Li, D.; Zhao, M.; Xu, Y.; Wei, Q. Multifunctional wearable smart device based on conductive reduced graphene oxide/polyester fabric. Appl. Surf. Sci. 2018, 454, 218-226. [CrossRef]

134. Pang, E.; Pickering, S.J.; Chan, A.; Wong, K.H. Use of recycled carbon fibre as a heating element. J. Compos. Mater. 2013, 47, 2039-2050. [CrossRef]

135. Ilanchezhiyan, P.; Zakirov, A.S.; Kumar, G.M.; Yuldashev, S.U.; Cho, H.D.; Kang, T.W.; Mamadalimov, A.T. Highly efficient CNT functionalized cotton fabrics for flexible/wearable heating applications. RSC Adv. 2015, 5, 10697-10702. [CrossRef]

136. Rahman, M.J.; Mieno, T. Conductive Cotton Textile from Safely Functionalized Carbon Nanotubes. J. Nanomater. 2015, 1-10. [CrossRef]

137. Neella, N.; Gaddam, V.; Rajanna, K.; Nayak, M.M. Low cost, disposable and wearable body warmer using RGO sheets coated on cloth substrate as heating element. In Proceedings of the 2017 IEEE 12th International Conference on Nano/Micro Engineered and Molecular Systems NEMS, Los Angeles, CA, USA, 9-12 April 2017; pp. 177-180. [CrossRef]

138. Ji, Y.; Li, Y.; Chen, G.; Xing, T. Fire-resistant and highly electrically conductive silk fabrics fabricated with reduced graphene oxide via dry-coating. Mater. Des. 2017, 133, 528-535. [CrossRef]

139. Bhattacharjee, S.; Joshi, R.; Chughtai, A.A.; Macintyre, C.R. Graphene Modified Multifunctional Personal Protective Clothing. Adv. Mater. Interfaces 2019, 6, 1-27. [CrossRef] 
140. Faruk, M.O.; Ahmed, A.; Jalil, M.A.; Islam, M.T.; Shamim, A.M.; Adak, B.; Hossain, M.M.; Mukhopadhyay, S. Functional textiles and composite based wearable thermal devices for Joule heating: Progress and perspectives. Appl. Mater. Today 2021, $23,1-23$. [CrossRef]

141. Zhang, X.; Wang, X.; Lei, Z.; Wang, L.; Tian, M.; Zhu, S.; Xiao, H.; Tang, X.; Qu, L. Flexible MXene-Decorated Fabric with Interwoven Conductive Networks for Integrated Joule Heating, Electromagnetic Interference Shielding, and Strain Sensing Performances. ACS Appl. Mater. Interfaces 2020, 12, 14459-14467. [CrossRef]

142. Kim, H.; Kim, H.S.; Lee, S. Thermal insulation property of graphene/polymer coated textile based multi-layer fabric heating element with aramid fabric. Sci. Rep. 2020, 10, 1-12. [CrossRef] [PubMed]

143. Jung, D.; Lee, K.H.; Kim, D.; Burk, D.; Overzet, L.J.; Lee, G.S. Highly conductive flexible multi-walled carbon nanotube sheet films for transparent touch screen. Jpn. J. Appl. Phys. 2013, 52, 1-6. [CrossRef]

144. Liu, Y.; Wang, X.; Qia, K.; Xin, J.H. Functionalization of cotton with carbon nanotubes. J. Mater. Chem. 2008, 18, 3454-3460. [CrossRef]

145. Zhou, J.; Zhao, Z.; Hu, R.; Yang, J.; Xiao, H.; Liu, Y.; Lu, M. Multi-walled carbon nanotubes functionalized silk fabrics for mechanical sensors and heating materials. Mater. Des. 2020, 191, 108636. [CrossRef]

146. Sui, D.; Huang, Y.; Huang, L.; Liang, J.; Ma, Y.; Chen, Y. Flexible and transparent electrothermal film heaters based on graphene materials. Small 2011, 7, 3186-3192. [CrossRef] [PubMed]

147. Pahalagedara, L.R.; Siriwardane, I.W.; Tissera, N.D.; Wijesena, R.N.; de Silva, K.M.N. Carbon black functionalized stretchable conductive fabrics for wearable heating applications. RSC Adv. 2017, 7, 19174-19180. [CrossRef]

148. Hossain, M.M.; Bradford, P. Industrially knittable CNT/cotton sheath-core yarns for smart textiles. In Proceedings of the SPIE Nano-, Bio-, Info-Tech Sensors, and 3D Systems IV, Online Only, CA, USA, 27 April-8 May 2020; Volume 1137809, pp. 1-6. [CrossRef]

149. Umair, M.M.; Zhang, Y.; Zhang, S.; Jin, X.; Tang, B. A novel flexible phase change composite with electro-driven shape memory, energy conversion/storage and motion sensing properties. J. Mater. Chem. A 2019, 7, 26385-26392. [CrossRef]

150. Levitt, A.; Zhang, J.; Dion, G.; Gogotsi, Y.; Razal, J.M. MXene-Based Fibers, Yarns, and Fabrics for Wearable Energy Storage Devices. Adv. Funct. Mater. 2020, 30, 1-22. [CrossRef]

151. Kim, H.; Lee, S. Characteristics of Electrical Heating Elements Coated with Graphene Nanocomposite on Polyester Fabric: Effect of Different Graphene Contents and Annealing Temperatures. Fibers Polym. 2018, 19, 965-976. [CrossRef]

152. Kong, K.; Cheedarala, R.K.; Kim, M.; Roh, H.D.; Park, Y.B.; Park, H.W. Electrical thermal heating and piezoresistive characteristics of hybrid CuO-woven carbon fiber/vinyl ester composite laminates. Compos. Part A Appl. Sci. Manuf. 2016, 85, 103-112. [CrossRef]

153. Kayacan, O.; Bulgun, E.; Sahin, O. Implementation of Steel-based Fabric Panels in a Heated Garment Design. Text. Res. J. 2009, 79, 1427-1437. [CrossRef]

154. Cui, J.; Zhou, S. Highly conductive and ultra-durable electronic textiles via covalent immobilization of carbon nanomaterials on cotton fabric. J. Mater. Chem. C 2018, 6, 12273-12282. [CrossRef]

155. Choi, H.N.; Jee, S.H.; Ko, J.; Kim, D.J.; Kim, S.H. Properties of surface heating textile for functional warm clothing based on a composite heating element with a positive temperature coefficient. Nanomaterials 2021, 11, 904. [CrossRef] [PubMed]

156. Fang, Y.; Chen, G.; Bick, M.; Chen, J. Smart textiles for personalized thermoregulation. Chem. Soc. Rev. 2021, 50, 9357-9374. [CrossRef]

157. Zheng, Y.; Zhang, Q.; Jin, W.; Jing, Y.; Chen, X.; Han, X.; Bao, Q.; Liu, Y.; Wang, X.; Wang, S.; et al. Carbon nanotube yarn based thermoelectric textiles for harvesting thermal energy and powering electronics. J. Mater. Chem. A 2020, 8, 2984-2994. [CrossRef]

158. Hong, S.; Gu, Y.; Seo, J.K.; Wang, J.; Liu, P.; Meng, Y.S.; Xu, S.; Chen, R. Wearable thermoelectrics for personalized thermoregulation. Sci. Adv. 2019, 5, 1-11. [CrossRef] [PubMed]

159. Liu, P.; Li, Y.; Xu, Y.; Bao, L.; Wang, L.; Pan, J.; Zhang, Z.; Sun, X.; Peng, H. Stretchable and Energy-Efficient Heating Carbon Nanotube Fiber by Designing a Hierarchically Helical Structure. Small 2018, 14, 1-6. [CrossRef]

160. Alberghini, M.; Hong, S.; Lozano, L.M.; Korolovych, V.; Huang, Y.; Signorato, F.; Zandavi, S.H.; Fucetola, C.; Uluturk, I.; Tolstorukov, M.Y.; et al. Sustainable polyethylene fabrics with engineered moisture transport for passive cooling. Nat. Sustain. 2021, 4, 715-724. [CrossRef]

161. Bisht, N.; More, P.; Khanna, P.K.; Abolhassani, R.; Mishra, Y.K.; Madsen, M. Progress of hybrid nanocomposite materials for thermoelectric applications. Mater. Adv. 2021, 2, 1927-1956. [CrossRef]

162. Cottet, D.; Grzyb, J.; Kirstein, T.; Tröster, G. Electrical Characterization of Textile Transmission Lines. IEEE Trans. Adv. Packag. 2003, 26, 182-190. [CrossRef]

163. Meyer, J.; Arnrich, B.; Schumm, J.; Troster, G. Design and modeling of a textile pressure sensor for sitting posture classification. IEEE Sens. J. 2010, 10, 1391-1398. [CrossRef]

164. Inaba, M.; Hoshino, Y.; Nagasaka, K.; Ninomiya, T.; Kagami, S.; Inoue, H. Full-body tactile sensor suit using electrically conductive fabric and strings. IEEE Int. Conf. Intell. Robot. Syst. 1996, 2, 450-457. [CrossRef]

165. Bonderover, E.; Wagner, S. A woven inverter circuit for e-textile applications. IEEE Electron Device Lett. 2004, $25,295-297$. [CrossRef]

166. Nouri, M.; Kish, M.H.; Entezami, A.A.; Edrisi, M. Conductivity of Textile Fibers Treated with Aniline. Iran. Polym. J. Engl. Ed. 2009, 9, 49-58. 
167. Varesano, A.; Dall'Acqua, L.; Tonin, C. A study on the electrical conductivity decay of polypyrrole coated wool textiles. Polym. Degrad. Stab. 2005, 89, 125-132. [CrossRef]

168. Kaynak, A.; Wang, L.; Hurren, C.; Wang, X. Characterization of conductive polypyrrole coated wool yarns. Fibers Polym. 2002, 3, 24-30. [CrossRef]

169. Kaynak, A.; Najar, S.S.; Foitzik, R.C. Conducting nylon, cotton and wool yarns by continuous vapor polymerization of pyrrole. Synth. Met. 2008, 158, 1-5. [CrossRef]

170. Najar, S.S.; Kaynak, A.; Foitzik, R.C. Conductive wool yarns by continuous vapour phase polymerization of pyrrole. Synth. Met. 2007, 157, 1-4. [CrossRef]

171. Xue, P.; Tao, X.M. Morphological and electromechanical studies of fibers coated with electrically conductive polymer. J. Appl. Polym. Sci. 2005, 98, 1844-1854. [CrossRef]

172. Hosseini, S.H.; Ali, P. Preparation of Conducting Fibres from Cellulose and Silk by Polypyrrole Coating. Iran. Polym. J. 2014, 11, 934-940.

173. Irwin, M.D.; Roberson, D.A.; Olivas, R.I.; Wicker, R.B.; MacDonald, E. Conductive polymer-coated threads as electrical interconnects in e-textiles. Fibers Polym. 2011, 12, 904-910. [CrossRef] 